\title{
Observations of relative humidity effects on aerosol light scattering in the Yangtze River Delta of China
}

\author{
L. Zhang ${ }^{1,2}$, J. Y. Sun ${ }^{1,3}$, X. J. Shen ${ }^{1}$, Y. M. Zhang ${ }^{1}$, H. Che ${ }^{1}$, Q. L. Ma ${ }^{4}$, Y. W. Zhang ${ }^{1}$, X. Y. Zhang ${ }^{1}$, and J. A. Ogren \\ ${ }^{1}$ Key Laboratory of Atmospheric Chemistry of CMA, Institute of Atmospheric Composition, \\ Chinese Academy of Meteorological Sciences, Beijing 100081, China \\ ${ }^{2}$ College of Earth Science, University of Chinese Academy of Sciences, Beijing 100049, China \\ ${ }^{3}$ State Key Laboratory of Cryospheric Sciences, Cold and Arid Region Environmental and Engineering Research Institute, \\ Chinese Academy of Sciences, Lanzhou 730000, China \\ ${ }^{4}$ Lin'an Regional Atmosphere Background Station, Lin'an 311307, China \\ ${ }^{5}$ Earth System Research Laboratory, NOAA, Boulder, CO, USA
}

Correspondence to: J. Y. Sun (jysun@cams.cma.gov.cn)

Received: 10 October 2014 - Published in Atmos. Chem. Phys. Discuss.: 29 January 2015

Revised: 26 June 2015 - Accepted: 9 July 2015 - Published: 28 July 2015

\begin{abstract}
Scattering of solar radiation by aerosol particles is highly dependent on relative humidity (RH) as hygroscopic particles take up water with increasing $\mathrm{RH}$. To achieve a better understanding of the effect of aerosol hygroscopic growth on light scattering properties and radiative forcing, the aerosol scattering coefficients at $\mathrm{RH}$ in the range of 40 to $\sim 90 \%$ were measured using a humidified nephelometer system in the Yangtze River Delta of China in March 2013. In addition, the aerosol size distribution and chemical composition were measured. During the observation period, the mean and standard deviation (SD) of enhancement factors at $\mathrm{RH}=85 \%$ for the scattering coefficient $(f(85 \%))$, backscattering coefficient $\left(f_{\mathrm{b}}(85 \%)\right)$, and hemispheric backscatter fraction $\left(f_{\beta}(85 \%)\right)$ were $1.58 \pm 0.12$, $1.25 \pm 0.07$, and $0.79 \pm 0.04$, respectively, i.e., aerosol scattering coefficient and backscattering coefficient increased by 58 and $25 \%$ as the RH increased from 40 to $85 \%$. Concurrently, the aerosol hemispheric backscatter fraction decreased by $21 \%$. The relative amount of organic matter (OM) or inorganics in $\mathrm{PM}_{1}$ was found to be a main factor determining the magnitude of $f(\mathrm{RH})$. The highest values of $f(\mathrm{RH})$ corresponded to the aerosols with a small fraction of OM, and vice versa. The relative amount of $\mathrm{NO}_{3}^{-}$in fine particles was strongly correlated with $f(85 \%)$, which suggests that $\mathrm{NO}_{3}^{-}$played a vital role in aerosol hygroscopic growth during this study. The mass fraction of nitrate also had a close relationship to the curvature of the humidograms; higher mass
\end{abstract}

fractions of nitrate were associated with humidograms that had the least curvature. Aerosol hygroscopic growth caused a $47 \%$ increase in the calculated aerosol direct radiative forcing at $85 \% \mathrm{RH}$, compared to the forcing at $40 \% \mathrm{RH}$.

\section{Introduction}

Hygroscopic aerosols take up water as humidity increases (Engelhart et al., 2011; Pilinis et al., 1989; Hänel, 1976; Covert et al., 1972). Aerosol water matters since water can affect both the size and refractive indices of atmospheric aerosols, thereby influencing the mass concentration, size distribution, and corresponding optical properties (e.g., scattering coefficient, backscattering coefficient, single scattering albedo, and asymmetry parameter) (Cheng et al., 2008; Randles et al., 2004; Malm et al., 2003; Carrico et al., 2003). In particular, understanding the effect of relative humidity on aerosol light scattering is important to better estimate radiative forcing and evaluate visibility impairment (Ackerman et al., 2004; Tang, 1996; Charlson et al., 1992; Covert et al., 1972). Additionally, most of the ground-based aerosol measurements are conducted in dry conditions to provide consistency within and among networks. These measurements can differ significantly from the ambient ones. Thus, the determination of enhancement factors for various optical variables are of crucial importance for climate forcing calcula- 
tions (Quinn et al., 1995; Pilinis et al., 1995) and the comparison between remote sensing and ground-based measurements (Zhang et al., 2012; Wang and Martin, 2007; Zieger et al., 2012).

The Yangtze River Delta, one of the most populated and fastest growing regions in China, has experienced extraordinary economic growth during the last two decades. Amounting to $2.1 \%$ of the land area of China, this region contains $\sim 11 \%$ of the country's population and produces $\sim 20 \%$ of China's gross domestic product (GDP) in 2013 (Wang et al., 2013). Concurrent with population increase and economic growth are the increasing energy consumption and number of automobiles, causing the Yangtze River Delta to become a significant source of gas and particulate pollutants and secondary aerosol production. A 5-week field campaign was carried out in the early winter of 1999 at Lin' an, a background station in the Yangtze River Delta (Xu et al., 2002). However, since then the physical and chemical properties of gas and particulate pollutants have changed dramatically with the rapidly developing economy and fast growing population, e.g., from 1999 to 2013, the sulfate mass concentration decreased from $21.2 \pm 11.5$ to $8.1 \pm 4.1$ (mean $\pm \mathrm{SD}$ ) (Qi et al., 2012; Xu et al., 2008; ZEPB, 1999, 2013). In order to better understand the aerosol light scattering properties and their dependency on relative humidity in the Yangtze River Delta, both the scattering and backscattering coefficients under dry ( $\mathrm{RH}<40 \%$ ) conditions and controlled, elevated relative humidity were measured, along with the chemical composition and particle number size distribution.

The enhancement factors discussed in this work include scattering enhancement factor $f(\mathrm{RH}, \lambda)$, enhancement factor for backscattering coefficient $f_{\mathrm{b}}(\mathrm{RH}, \lambda)$, and enhancement factor for hemispheric backscatter fraction $f_{\beta}(\mathrm{RH}, \lambda)$. The impact of relative humidity on the aerosol light scattering coefficient is called the scattering enhancement factor $f(\mathrm{RH}, \lambda)$, defined as

$f(\mathrm{RH}, \lambda)=\sigma_{\mathrm{sp}}(\mathrm{RH}, \lambda) / \sigma_{\mathrm{sp}}(\operatorname{dry}, \lambda)$,

where $\sigma_{\mathrm{sp}}(\mathrm{dry}, \lambda)$ and $\sigma_{\mathrm{sp}}(\mathrm{RH}, \lambda)$ represent scattering coefficients at wavelength $\lambda$ in dry conditions and at a defined higher relative humidity, respectively.

Likewise, the impact of relative humidity on aerosol backscattering coefficient can be described as the enhancement factor for backscattering coefficient $f_{\mathrm{b}}(\mathrm{RH}, \lambda)$ :

$f_{\mathrm{b}}(\mathrm{RH}, \lambda)=\sigma_{\mathrm{bsp}} / \sigma_{\mathrm{bsp}}(\operatorname{dry}, \lambda)$,

where $\sigma_{\mathrm{bsp}}(\mathrm{dry}, \lambda)$ and $\sigma_{\mathrm{bsp}}(\mathrm{RH}, \lambda)$ represent backscattering coefficients at wavelength $\lambda$ in dry conditions and at a defined relative humidity, respectively. $f(\mathrm{RH}, \lambda)$ and $f_{\mathrm{b}}(\mathrm{RH}, \lambda)$ are always greater than 1 if no significant restructuring has taken place after water uptake (Weingartner et al., 1995).

Hemispheric backscatter fraction $\left(b=\sigma_{\mathrm{bsp}} / \sigma_{\mathrm{sp}}\right)$ is closely related to the upscatter fraction $(\bar{\beta})$, the fraction of incident solar radiation scattered into space (Wiscombe and Grams,
1976). The impact of relative humidity on aerosol hemispheric backscatter fraction can be defined as the enhancement factor for hemispheric backscatter fraction $f_{\beta}(\mathrm{RH}, \lambda)$ :

$f_{\beta}(\mathrm{RH}, \lambda)=b(\mathrm{RH}, \lambda) / b(\operatorname{dry}, \lambda)$,

where $b(\mathrm{dry}, \lambda)$ and $b(\mathrm{RH}, \lambda)$ represent hemispheric backscatter fraction at wavelength $\lambda$ in dry conditions and at the defined relative humidity. Thus, $f_{\beta}(\mathrm{RH}, \lambda)$ can be rewritten as $f_{\beta}(\mathrm{RH}, \lambda)=f_{\mathrm{b}}(\mathrm{RH}, \lambda) / f(\mathrm{RH}, \lambda)$.

The wavelength dependence of scattering enhancement factor $f(\mathrm{RH}, \lambda)$ varies with generalized aerosol types. Kotchenruther and Hobbs (1998) and Zieger et al. (2010, 2011) found no pronounced wavelength dependence of $f(\mathrm{RH}, \lambda)$ for biomass burning aerosols and arctic aerosols, respectively; Zieger et al. (2013) found small variations $(<5 \%)$ of $f(\mathrm{RH}, \lambda)$ at 450,550 , and $700 \mathrm{~nm}$ for several European sites; Kotchenruther et al. (1999) and Magi and Hobbs (2003) reported significant wavelength dependence of $f(\mathrm{RH}, \lambda)$ for urban/industrial aerosols off the east coast of the United States. In this study, the wavelength dependence of enhancement factors was also investigated. Except when specially mentioned, all the parameters discussed in this study are based on the measurements at $550 \mathrm{~nm}$ wavelength only.

\section{Experimental sites and instrumentation}

\subsection{Site description}

This study was carried out during an intensive field sampling period from 1 to 31 March 2013 at Lin'an Regional Atmosphere Background Station, which is a WMO Global Atmosphere Watch regional station $\left(30.3^{\circ} \mathrm{N}, 119.73^{\circ} \mathrm{E}, 138 \mathrm{~m}\right.$ a.s.l.) located in the center of the Yangtze River Delta, China (Fang et al., 2013) (as shown in Fig. 1). It is approximately $11 \mathrm{~km}$ north of the city of Lin'an, with a population of 1.5 million. The site is $\sim 50 \mathrm{~km}$ west of Hangzhou (capital of Zhejiang Province with a population of $\sim 8.8$ million) and $\sim 210 \mathrm{~km}$ southwest of Shanghai (a megacity with a population of $\sim 20$ million). Lin'an station is on the top of a small hill, in an area primarily covered by bamboo forests and rice paddies, and represents the background conditions of the Yangtze River Delta. North of the station is a small village with $\sim 200$ inhabitants. In addition, there is an activated charcoal factory $\sim 1.4 \mathrm{~km}$ north of Lin'an station that uses bamboo wood as its source material (Qi et al., 2012). During the observation period, the prevailing winds were northeasterly (NE) and southwesterly (SW) with an average wind speed of $\sim 2.5 \mathrm{~m} \mathrm{~s}^{-1}$ (SD $1.4 \mathrm{~m} \mathrm{~s}^{-1} .72 \mathrm{~h}$ back trajectories showed two contrasting air mass origins: (1) air masses from northern China through long-distance transport and (2) air masses from the south/southwest with a much shorter transport distance. 


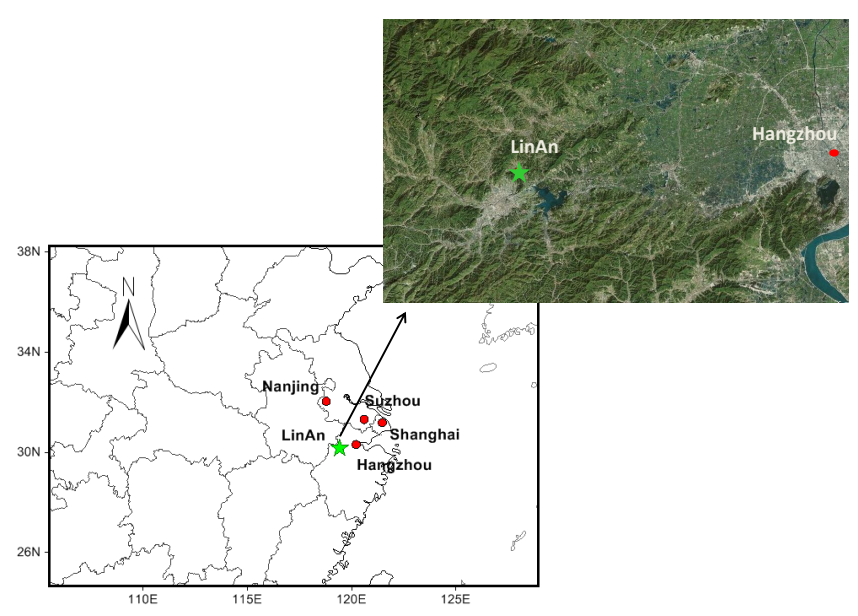

Figure 1. Location of Lin' an station (green star) and the main cities in the Yangtze River Delta (red dots) in the lower left panel. The upper right panel shows the topography of the surrounding area.

\subsection{Measurement system and data processing}

The scattering enhancement factor $f(\mathrm{RH})$ is defined as the ratio of aerosol scattering coefficient at a given, elevated $\mathrm{RH}$ to that at a low RH (usually $<40 \%$ ). Correspondingly, the humidification system, called a humidograph, included two nephelometers operating in series with a humidifier between them. Sample air entered the first nephelometer (reference nephelometer or DryNeph) through an aerosol dryer (Shen et al., 2011; Tuch et al., 2009) to ensure the aerosol was at dry conditions (RH inside DryNeph was $12.2 \pm 3.4 \%$ (mean $\pm \mathrm{SD}$ ) for the whole field campaign), then passed through the humidifier, where the sample RH was regulated to a higher RH that was ramped from $\sim 40$ to $90 \%$, and finally entered the second nephelometer (humidified nephelometer or WetNeph) where the scattering coefficient of humidified aerosols was measured.

Aerosol total scattering (between 7 and $170^{\circ}$ ) and backscattering coefficients (between 90 and $170^{\circ}$ ) were measured with an integrating nephelometer (TSI Inc., Model $3563)$ at three wavelengths: blue $(450 \mathrm{~nm})$, green $(550 \mathrm{~nm})$, and red $(700 \mathrm{~nm})$. Data were recorded as $1 \mathrm{~min}$ averages and a zero check was performed automatically once per hour. The detailed characteristics of this instrument have been described in many previous studies (Anderson and Ogren, 1998; Charlson et al., 1969; Anderson et al., 1996).

The humidifier was built by the aerosol group in Global Monitoring Division, Earth System Research Laboratory, National Ocean \& Atmospheric Administration, USA (NOAA/GMD), based on the design described in Carrico et al. (1998). It consisted of two concentric tubes with a heater and insulation around the outer tube. Sample air flowed through the inner tube, while water circulated between the inner and outer tubes. The inner tube was made of porous extruded PTFE (polytetrafluoroethylene) membrane, whose pore size is large enough for water molecules, but too small for larger molecules such as oxygen to cross. The flux of water vapor through the membrane was controlled by regulating the electric current to the humidifier heater until the desired $\mathrm{RH}$ was attained. The humidity scan was a $1 \mathrm{~h}$ cycle; $\mathrm{RH}$ was ramped from $\sim 40$ to $90 \%$ during the first half hour and in the reverse direction during the last half hour.

Besides the scattering measurement, particle number size distribution and aerosol chemistry were also measured at the station. Particle number size distributions from $3 \mathrm{~nm}$ to $10 \mu \mathrm{m}$ were measured with a twin differential mobility particle sizer (TDMPS) (Birmili et al., 1999) and an aerodynamic particle sizer (APS, model 3321, TSI Inc.). The mass concentrations of sulfate, nitrate, ammonium, organic matter (OM) and chloride (aerodynamic diameter less than $1 \mu \mathrm{m}$ ) were measured with an aerosol mass spectrometer (AMS, Aerodyne Inc.). The equivalent mass concentration of black carbon (EBC) was measured with a multi angle absorption photometer (MAAP, model 5012, Thermo Scientific Inc.) at $637 \mathrm{~nm}$ wavelength (Müller et al., 2011); the assumed mass absorption cross-section was $6.6 \mathrm{~m}^{2} \mathrm{~g}^{-1}$. Visibility was measured using a near-forward scattering sensor (FD12, Vaisala). Meteorological data were provided by the Lin'an Regional Atmosphere Background Station.

All the instruments were housed in a measurement laboratory where room temperature was controlled at $\sim 25^{\circ} \mathrm{C}$. All data were reported in Beijing Time (BJT; UTC +8$)$ and all the scattering data were referenced at $T=0{ }^{\circ} \mathrm{C}$ and $P=$ $1013.25 \mathrm{hPa}$. The truncation error correction described by Anderson and Ogren (1998) was applied to retrieve the final scattering and backscattering coefficients. The Ångström exponent $\alpha$, defined as $\alpha=-\log \left[\sigma_{\mathrm{sp}}\left(\lambda_{1}\right) / \sigma_{\mathrm{sp}}\left(\lambda_{2}\right)\right] / \log \left[\lambda_{1} / \lambda_{2}\right]$, represents the wavelength dependence of light scattering assuming a power law relationship of $\sigma_{\mathrm{sp}}$ and $\sigma_{\mathrm{bsp}}$ with wavelength. In this study, scattering coefficients at $450 \mathrm{~nm}$ and $700 \mathrm{~nm}$ were used to derive $\alpha$. Normalization of $f(\mathrm{RH})$ (Day and Malm, 2001) has been carried out to get the final $f(\mathrm{RH})$ scan values, i.e., $f(40 \%$ ) (the lowest $\mathrm{RH}$ in one cycle) is set to 1 and used to normalize other $f(\mathrm{RH})$ values in this cycle. It is worth mentioning that the normalization of $f(\mathrm{RH})$ (see Sect. 2.2) may underestimate $f(\mathrm{RH})$ to some extent, since some organics (e.g., humic acid sodium) take up water even when RH $<40 \%$ (Sjogren et al., 2007; Dick et al., 2000). To evaluate its impact, we calculated the raw $f(40 \%)$ value without the normalization. The average and standard deviation were 1.03 and 0.03 with a maximum of 1.08 , which means this normalization may cause an underestimate of $5 \%$ (an error of $3 \%$ was caused by the inconsistency of DryNeph and WetNeph, see Sect. 2.4) at most. Figure 2c shows the unnormalized $f(\mathrm{RH})$ value; the lowest value of each cycle was around 1.03, which represents the inconsistency of DryNeph and WetNeph. 

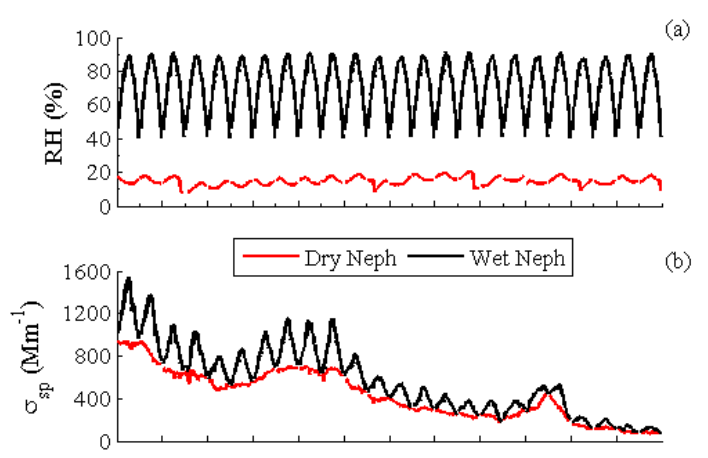

(c)

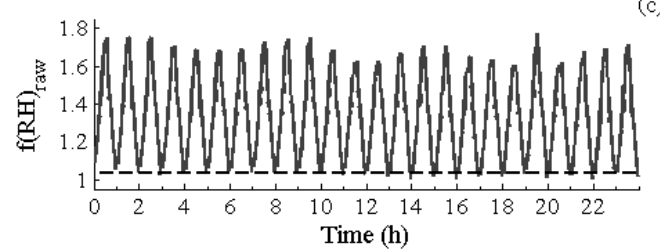

Figure 2. Example of measured data on 17 March 2013. (a) Relative humidity inside DryNeph (red line) and WetNeph (black line); (b) aerosol scattering coefficients measured by DryNeph (red line) and WetNeph (black line) at $550 \mathrm{~nm}$ wavelength; (c) raw scattering enhancement factor $f(\mathrm{RH}, 550 \mathrm{~nm})$ raw without normalization, the black dashed line is at $f(\mathrm{RH})_{\text {raw }}=1.03$.

\subsection{Inlet system}

An automatic regenerating adsorption aerosol dryer (Tuch et al., 2009) was used to provide low RH sample air to DryNeph, TDMPS, APS, AMS, and MAAP to ensure comparability of measurements. The aerosol dryer was housed in a separate shelter that was located on the rooftop ( $\sim 5$ m a.g.l.) of the measurement laboratory. Sample air entered the shelter through a commercially available $\mathrm{PM}_{10}$ impactor $\left(\mathrm{PM}_{10}\right.$ inlet, URG Corporation) and then passed through the adsorption aerosol dryer (Tuch et al., 2009) to reduce the $\mathrm{RH}$ to less than $30 \%$. The dried sample air passed through a $3 / 4$ in. diameter stainless tube to a manifold, which split the sample into $1 / 4$ or $3 / 8$ in. diameter tubes that connected to the different instruments. The total sample flow through the $\mathrm{PM}_{10}$ impactor was kept at $16.7 \mathrm{~L} \mathrm{~min}^{-1}$ to ensure a $50 \%$ collection efficiency at $10 \mu \mathrm{m}$ aerodynamic diameter (Berner et al., 1979).

\subsection{Quality control}

Accurate performance of nephelometers and $\mathrm{RH}$ sensors is crucial to retrieve reliable enhancement factors $\left(f(\mathrm{RH}, \lambda), f_{\mathrm{b}}(\mathrm{RH}, \lambda)\right.$ and $\left.f_{\beta}(\mathrm{RH}, \lambda)\right)$, since they are defined as the aerosol scattering coefficient/backscattering coefficient/hemispheric backscatter fractions at a higher RH than those at a low RH (usually < $40 \%$ ). In addition, the RH control in the WetNeph sensing volume is also critical to $f(\mathrm{RH})$ measurement. Therefore, several comparisons and calibra- tions have been carried out before and during the experiment. Three external RH sensors (Vaisala, model HMP60) were calibrated in the RH range of 11 to $80 \%$ using a Vaisala Humidity Calibrator (HMK15) with four saturated salt solutions ( $\left.\mathrm{LiCl}, \mathrm{K}_{2} \mathrm{CO}_{3}, \mathrm{NaCl},\left(\mathrm{NH}_{4}\right)_{2} \mathrm{SO}_{4}\right)$, and a humidity/temperature transmitter (Vaisala, model HMT333), which was calibrated by the National Center for Meteorological Metrology, China. The two internal nephelometer RH sensors were calibrated to the external RH sensors with an uncertainty of $\leq 2 \%$. A good agreement of these RH sensors was achieved with a discrepancy of $<3 \%$. Both nephelometers were calibrated with $\mathrm{CO}_{2}$ (purity $99.999 \%$ ) and filtered air. Filtered air measurements were made automatically every hour to track the instrument background. Comparison of scattering and backscattering coefficients of the two nephelometers at low RH $(9.6 \pm 3.2 \%)$ was performed during 1 to 3 March 2013. The total scattering coefficient and backscattering coefficient measured by WetNeph were constantly $3 \%\left(y=1.03 \times+1.60, R^{2}=1.000\right)$ and $4 \%\left(y=1.04 \times+0.09, R^{2}=0.997\right)$ higher than those obtained by DryNeph at $550 \mathrm{~nm}$ (similarly for other wavelengths); the high consistency demonstrates that the two nephelometers were operating quite steadily and the scattering/backscattering coefficients measured by DryNeph can be corrected in order to make them comparable to the measurements of WetNeph. The uncertainty of nephelometer measurements is $\sim 10 \%$ (Anderson et al., 1996), which, when combined with the uncertainty of the measurements of the internal RH sensors, yields an uncertainty for $f(85 \%)$ of $\sim 20 \%$. This overall uncertainty could be lower for less hygroscopic particles or lower RHs.

The RH at the outlet of WetNeph was regulated via a feedback system using the Vaisala RH signal, a proportionalintegral-derivative controller, and a heater. The humidifier set point was stepped from low to high RH and back to low RH every hour with the set point changing every 1 or $2 \mathrm{~min}$. Figure 2 is an example of our data showing the RH control and corresponding scattering measurements. As can be seen from Fig. 2, good RH control was achieved regardless of the magnitude of the scattering coefficient.

During the drying and humidifying process, thermophoresis, coagulation, evaporation, and irreversible chemical reactions can alter the particles from the original ones. A variety of measures were taken to minimize changes to the particles: the transport path was made as short and straight as possible, particle-free air was diluted to the aerosol stream to reduce coagulation, and higher heater temperatures were avoided to reduce evaporation of semi-volatile compounds like weak organic acids and nitrates. The nephelometers were operated at a constant flow of $20 \mathrm{~L} \mathrm{~min}^{-1}$, comprised of $9 \mathrm{~L} \mathrm{~min}^{-1}$ sample air and $11 \mathrm{~L} \mathrm{~min}^{-1}$ particle-free air (dilution flow). The total flow rate through the nephelometer was controlled by a mass flow controller. The dilution flow was regulated by a needle valve and measured with a mass flow meter. The sample and dilution flow were calibrated with a Gilibrator bubble 


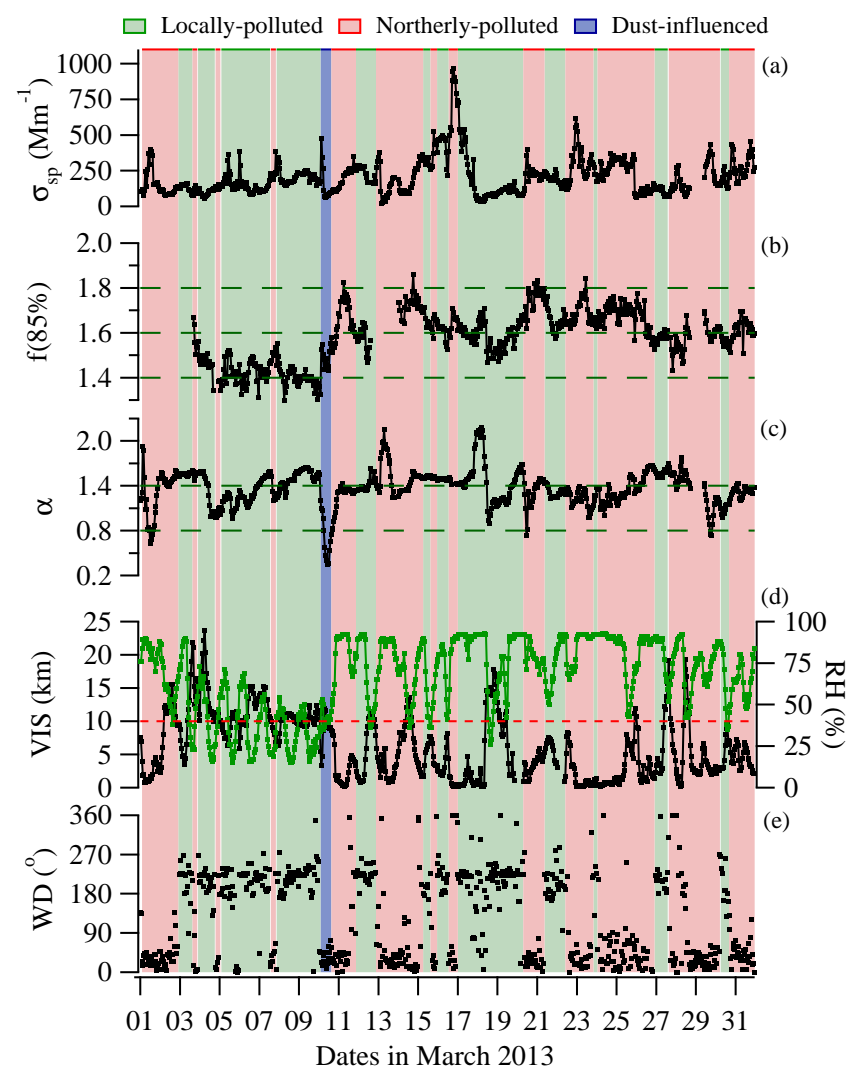

Figure 3. Time series of measured and derived aerosol variables and the ambient RH and visibility. (a) Aerosol scattering coefficient of DryNeph at $550 \mathrm{~nm}$ wavelength; (b) scattering enhancement factor $f(85 \%)$ at $550 \mathrm{~nm}$ wavelength; (c) Ångström exponent $\alpha$; (d) visibility (VIS) and relative humidity (RH) at ambient conditions, the red dashed line represents VIS $=10 \mathrm{~km}$; (e) wind direction (WD), indicating that prevailing wind directions during the observation period were mainly northeasterly (NE) and southwesterly (SW).

flow meter before the experiment. Filtered air tests were also conducted to make sure that all the instruments were in good condition and that there were no leaks in the system.

\section{Results and discussion}

\subsection{Overview}

Figure 3 shows the time series of the measured and derived aerosol variables during March 2013, as well as the ambient RH and visibility. The scattering enhancement factor $f(85 \%)$ ranged from 1.29 to 1.86 (Fig. 3a) with an average of 1.58 (Table 1) for the whole campaign. During 49 March, when Lin'an was dominated by air masses from the south under clear skies, $f(85 \%)$ stayed at a low value of $1.42( \pm 0.05)$. In March, the hourly averaged aerosol scattering coefficient, measured under dry conditions (Fig. 3c), varied from 21 to $1067 \mathrm{M} \mathrm{m}^{-1}$, and the maximum occurred on 16 March, when severe haze occurred. The mean value and
Table 1. Averaged enhancement factors and mean standard deviations for scattering coefficient, backscattering coefficient, and hemispheric backscatter fraction at different RHs (550 nm wavelength).

\begin{tabular}{cccc}
\hline $\mathrm{RH}(\%)$ & $f(\mathrm{RH})$ & $f_{\mathrm{b}}(\mathrm{RH})$ & $f_{\beta}(\mathrm{RH})$ \\
\hline 50 & $1.07(0.04)$ & $1.04(0.02)$ & $0.96(0.02)$ \\
60 & $1.14(0.08)$ & $1.06(0.04)$ & $0.93(0.04)$ \\
70 & $1.24(0.11)$ & $1.10(0.05)$ & $0.89(0.05)$ \\
80 & $1.43(0.12)$ & $1.18(0.07)$ & $0.83(0.05)$ \\
85 & $1.58(0.12)$ & $1.25(0.07)$ & $0.79(0.04)$ \\
\hline
\end{tabular}

standard deviation of the hourly averaged aerosol scattering coefficient was $223 \mathrm{M} \mathrm{m}^{-1}\left(140 \mathrm{M} \mathrm{m}^{-1}\right)$. Visibility (Fig. 3b) varied from 0.1 to $23.7 \mathrm{~km}$ at ambient conditions with a mean value of $6.2 \mathrm{~km}$. The lowest visibility was observed on 23 and 24 March, when the station was in clouds. From 15 to 16 March, visibility declined to $4.4 \mathrm{~km}$ with the accumulation of pollutants in the atmosphere, which was a severe haze episode (as mentioned above). An air mass from northwest China with high dust levels arrived at Lin'an on 10 March, with an abrupt increase of the aerosol scattering coefficient (Fig. 3c) and a sharp decline of Ångström exponent (Fig. 3d).

Based on nephelometer measurements, the enhancement factors for scattering coefficient $f(\mathrm{RH})$, backscattering coefficient $f_{\mathrm{b}}(\mathrm{RH})$, and hemispheric backscatter fraction $f_{\beta}(\mathrm{RH})$ were determined using Eqs. (1), (2), and (3), respectively. Their values at different RHs $(50,60,70,80$, and $85 \%)$ were obtained using linear interpolation from the half-hourly humidogram data (Table 1). The enhancement factors $f(\mathrm{RH})$ and $f_{\mathrm{b}}(\mathrm{RH})$ increased as the $\mathrm{RH}$ increased, but $f_{\mathrm{b}}(\mathrm{RH})$ increased much more slowly than $f(\mathrm{RH})$. The $f(85 \%)$ and $f_{\mathrm{b}}(85 \%)$ were 1.58 and 1.25 , respectively, suggesting that the scattering coefficient and backscattering coefficient at $85 \% \mathrm{RH}$ were 58 and $25 \%$ higher than those in dry conditions due to aerosol water uptake. The $f_{\beta}(\mathrm{RH})$ decreased with increasing RH, i.e., the hemispheric backscatter fraction becomes smaller with the increase of $\mathrm{RH}$, and the fraction of radiation that would have been backscattered into space was reduced. The $f_{\beta}(\mathrm{RH})$ decreased $\sim 21 \%$ as the $\mathrm{RH}$ increased from 40 to $85 \%$. All these parameters are of crucial importance in evaluating the aerosol radiative forcing.

Generally, the scattering enhancement factor $(f(80 \%)=1.44)$ is much lower than the result $(f(80 \%)=1.7-2.1)$ obtained by $\mathrm{Xu}$ et al. (2002) for Lin'an in 1999. This value is also lower than the results obtained by Carrico during ACE-1 (Aerosol Characterization Experiment; Carrico et al., 1998) and ACE-Asia (Asian Pacific Regional Aerosol Characterization Experiment; Carrico et al., 2003), the values obtained by Zieger et al. (2013) in several European sites and the Arctic, and the values reported at several sites in the US (Malm et al., 2005, 2003; Malm and Day, 2001, 2000; Day and Malm, 2001). However, the differences between measured $f(\mathrm{RH})$ in this 
Table 2. Summary of mass concentrations $\left(\mu \mathrm{g} \mathrm{m}^{-3}\right)$ of aerosol species measured by AMS and MAAP* (SD: standard deviation).

\begin{tabular}{lrrrr}
\hline & Mean & SD & Minimum & Maximum \\
\hline Sulfate & 8.1 & 4.1 & 0.1 & 26.1 \\
Nitrate & 9.8 & 12.1 & 0.2 & 79.2 \\
Ammonium & 6.9 & 5.5 & 0.5 & 42.8 \\
Chloride & 1.1 & 2.0 & 0.002 & 22.9 \\
OM & 17.7 & 11.1 & 2.8 & 93.9 \\
EBC $^{*}$ & 4.1 & 2.8 & 0.7 & 25.3 \\
\hline
\end{tabular}

* EBC was measured by MAAP in $\mathrm{PM}_{10}$.

study and previous studies performed in China (Yan et al., 2009; Pan et al., 2009; Liu et al., 2009; Cheng et al., 2008) are much smaller. The enhancement factors for backscattering coefficient and hemispheric backscatter fraction $\left(f_{\mathrm{b}}(85 \%)\right.$ and $f_{\beta}(85 \%)$ ) were $1.25(0.07)$ and $0.79(0.04)$, respectively, similar to the results $\left(f_{\mathrm{b}}(82 \%)=1.22 \pm 0.06\right.$ and $\left.f_{\beta}(82 \%)=0.83\right)$ obtained by Carrico at Sagres, Portugal during the second Aerosol Characterization Experiment (ACE-2; Carrico et al., 2000), and the results $\left(f_{\mathrm{b}}(82 \%)=1.27\right.$ and $\left.f_{\beta}(82 \%)=0.75\right)$ obtained by Carrico et al. (2003) during the dust-dominant period in ACE-Asia.

\subsection{Aerosol chemical properties}

The submicron mass concentrations of sulfate, nitrate, ammonium, chloride, and organic matter (OM) measured by AMS, plus EBC in $\mathrm{PM}_{10}$ measured by MAAP, are summarized in Table 2. The mass concentration of OM is the largest, while the mass concentration of chloride is the smallest, in agreement with previous studies in Lin'an (Meng et al., 2012; Yan et al., 2005). The mean mass concentrations of nitrate and sulfate were $9.8 \pm 12.1$ and $8.1 \pm 4.1 \mu \mathrm{g} \mathrm{m}^{-3}$ in this study, similar to the values $\left(9.4 \pm 7.1 \mu \mathrm{g} \mathrm{m}^{-3}\right.$ for nitrate and $8.6 \pm 3.7 \mu \mathrm{g} \mathrm{m}^{-3}$ for sulfate in $\left.\mathrm{PM}_{2.5}\right)$ at Lin'an in summer, 2010 (Meng et al., 2012).

Aerosol acidity is a key parameter affecting aerosol hygroscopic growth. It is usually examined by comparing the $\mathrm{NH}_{4}^{+}$ mass concentration and the amount needed to fully neutralize sulfate, nitrate, and chloride ions $\left(\mathrm{NH}_{4}^{+}\right.$predicted) (Sun et al., 2010):

$$
\begin{aligned}
\mathrm{NH}_{4}^{+} \text {predicted }= & 18 \times\left(2 \times \mathrm{SO}_{4}^{2-} / 96+\mathrm{NO}_{3}^{-} / 62\right. \\
& \left.+\mathrm{Cl}^{-} / 35.5\right)
\end{aligned}
$$

Figure 4 illustrates the relationship of measured $\mathrm{NH}_{4}^{+}$and predicted $\mathrm{NH}_{4}^{+}$. As shown in Fig. 4, the regression slope is close to 1 , which implies that there was sufficient $\mathrm{NH}_{3}$ in the atmosphere to neutralize $\mathrm{H}_{2} \mathrm{SO}_{4}, \mathrm{HNO}_{3}$, and $\mathrm{HCl}$, and that the $\mathrm{PM}_{1}$ aerosol at Lin'an was bulk neutralized during the measurement period. Therefore, the dominant chemical form of sulfate aerosol is ammonium sulfate rather than acidic sul-

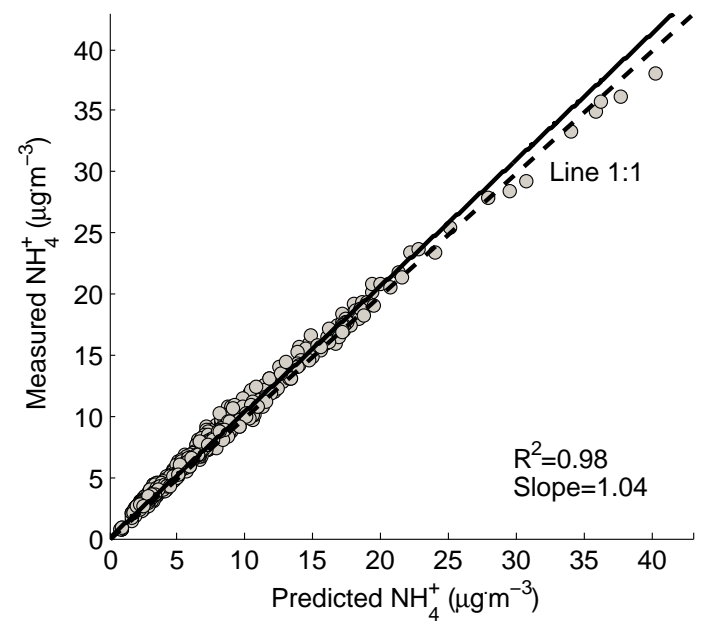

Figure 4. Measured and predicted mass concentration of ammonium. The predicted mass concentration of ammonium $\left(\mathrm{NH}_{4_{\text {predicted }}^{+}}\right)$ is calculated by Eq. (4). The solid black line represents the linear least square regression.

fate $\left(\mathrm{H}_{2} \mathrm{SO}_{4}\right.$ or $\left.\mathrm{NH}_{4} \mathrm{HSO}_{4}\right)$, and nitrate existed in the form of $\mathrm{NH}_{4} \mathrm{NO}_{3}$. By calculating Pearson's correlation coefficient among five different chemical species, it was found that $\mathrm{NH}_{4}^{+}$ and $\mathrm{NO}_{3}^{-}$are strongly correlated with $r=0.93 ; \mathrm{NH}_{4}^{+}$and $\mathrm{SO}_{4}^{2-}, \mathrm{Cl}^{-}$are highly related with $r$ equal to 0.77 and 0.74 respectively. This also implies the main form of inorganics would be $\mathrm{NH}_{4} \mathrm{NO}_{3},\left(\mathrm{NH}_{4}\right)_{2} \mathrm{SO}_{4}$, and $\mathrm{NH}_{4} \mathrm{Cl}$. However, the average mass concentration of chloride was very low (see Table 2) at Lin'an, and $\mathrm{NH}_{4} \mathrm{NO}_{3}$ and $\left(\mathrm{NH}_{4}\right)_{2} \mathrm{SO}_{4}$ were the dominant water-soluble ionic species, consistent with previous results at Lin'an based on filter chemical measurements (Meng et al., 2012).

\subsection{Wavelength dependence of the scattering enhancement factor $f(85 \%)$}

The wavelength dependence of the scattering enhancement factor is needed to estimate the aerosol radiative forcing since solar radiation at Earth's surface depends on wavelength. The histogram for $f(85 \%, 550 \mathrm{~nm})$ is shown in Fig. 5. Overlaid on the histogram for $f(85 \%, 550 \mathrm{~nm}$ ) (Fig. 5) are Gaussian curves based on the statistics for $f(85 \%)$ at each wavelength. No apparent shift of mean $f(85 \%)$ is seen for the $550 \mathrm{~nm}$ and $700 \mathrm{~nm}$ wavelength pair (see Fig. 5), while the mean $f(85 \%$, $450 \mathrm{~nm}$ ) is $\sim 6 \%$ lower than that at $550 \mathrm{~nm}$ with a smaller standard deviation (see Fig. 5). For higher values (90th and 70th percentile values in Table 3), a slight wavelength dependence of $f(\mathrm{RH})$ can be observed, i.e., the $f(\mathrm{RH})$ increases with the increase of wavelength. However, the differences are mostly under $10 \%$ and therefore the discussion is focused on $550 \mathrm{~nm}$ wavelength in this study. Similar results were obtained by Zieger at a regional continental research site in Melpitz, Germany (Zieger et al., 2014). 
Table 3. Statistical values of $f(85 \%)$ at 450,550 , and $700 \mathrm{~nm}$ wavelengths (SD: standard deviation; prctl: percentile).

\begin{tabular}{cccccccc}
\hline$\lambda$ & mean & SD & 90th pretl. & 75th prctl. & median & 25th prctl. & 10th prctl. \\
\hline $450 \mathrm{~nm}$ & 1.51 & 0.09 & 1.63 & 1.58 & 1.53 & 1.47 & 1.39 \\
$550 \mathrm{~nm}$ & 1.58 & 0.12 & 1.72 & 1.65 & 1.59 & 1.49 & 1.40 \\
$700 \mathrm{~nm}$ & 1.59 & 0.15 & 1.77 & 1.70 & 1.62 & 1.46 & 1.36 \\
\hline
\end{tabular}

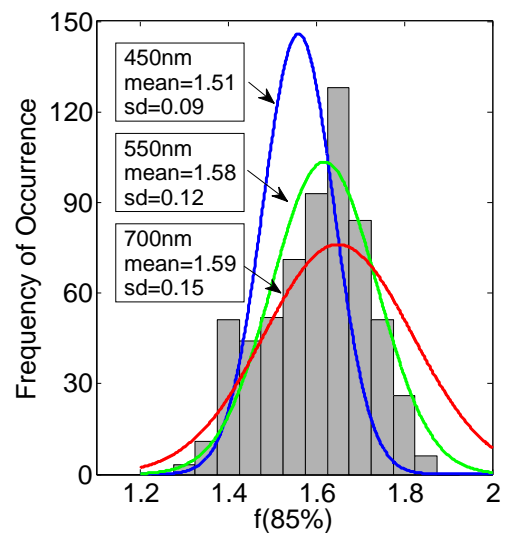

Figure 5. Histogram of $f(85 \%, 550 \mathrm{~nm})$ overlaid with the Gaussian curves based on the statistics for $f(85 \%, 450 \mathrm{~nm}), f(85 \%$, $550 \mathrm{~nm})$, and $f(85 \%, 700 \mathrm{~nm})$.

Table 4. Average enhancement factors and mean standard deviations for scattering coefficient, backscattering coefficient, and hemispheric backscatter fraction in various observation episodes (550 nm wavelength).

\begin{tabular}{llll}
\hline & $\begin{array}{l}\text { Locally } \\
\text { polluted }\end{array}$ & $\begin{array}{l}\text { Northerly } \\
\text { polluted }\end{array}$ & $\begin{array}{l}\text { Dust- } \\
\text { influenced }\end{array}$ \\
\hline$f(80 \%)$ & $1.36(0.11)$ & $1.50(0.09)$ & $1.37(0.05)$ \\
$f_{\mathrm{b}}(80 \%)$ & $1.15(0.06)$ & $1.21(0.06)$ & $1.15(0.03)$ \\
$f_{\beta}(80 \%)$ & $0.85(0.04)$ & $0.81(0.03)$ & $0.84(0.03)$ \\
$f(85 \%)$ & $1.52(0.10)$ & $1.64(0.09)$ & $1.48(0.05)$ \\
$f_{\mathrm{b}}(85 \%)$ & $1.21(0.06)$ & $1.28(0.06)$ & $1.19(0.04)$ \\
$f_{\beta}(85 \%)$ & $0.80(0.02)$ & $0.78(0.02)$ & $0.81(0.03)$ \\
$N$ & 295 & 303 & 14 \\
\hline
\end{tabular}

\subsection{Classification of various observation episodes}

Based on wind direction, back trajectory analysis and weather phenomena, the observation period can be classified into three main sectors: a northerly polluted period (influenced by long-distance transport from northern China), a locally polluted period, and a dust-influenced episode. Air mass back trajectories over $72 \mathrm{~h}$ at $300 \mathrm{~m}$ a.g.l. arrival height were calculated using the Trajectory Statistics (TrajStat) model (Wang et al., 2009) with 6-hourly archived meteorological data provided by the US National Centers for Environmental Prediction (NCEP). The characteristics of these three periods are as follows:

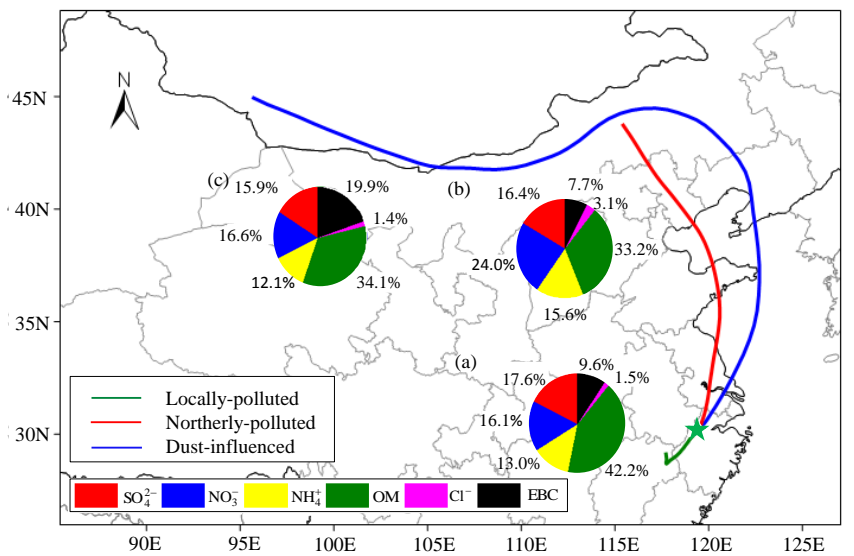

Figure 6. $72 \mathrm{~h}$ back trajectories of locally polluted, northerly polluted, and dust-influenced periods, together with the mean mass fractions of submicron chemical species $\left(\mathrm{SO}_{4}^{2-}, \mathrm{NO}_{3}^{-}, \mathrm{NH}_{4}^{+}, \mathrm{OM}\right.$ and $\mathrm{Cl}^{-}$) measured by $\mathrm{AMS}$ and $\mathrm{EBC}$ in $\mathrm{PM}_{10}$ measured by MAAP. The pie charts (a), (b), and (c) are for locally polluted, northerly polluted, and dust-influenced periods, respectively.

1. Periods when the wind direction is between 120 and $270^{\circ}$ are labeled as "locally polluted periods". During these periods, pollutants mostly came from Anhui Province, Jiangxi Province, the southern region of Zhejiang Province, and Lin'an (green line in Fig. 6). The economy in these areas is mainly made up of manufacturing, tourism, and agriculture.

2. Periods when the wind direction was greater than 270 or less than $120^{\circ}$ are described as "northerly polluted periods". Back trajectories indicate that most of the air masses came from northern China and passed over heavily polluted areas such as the Beijing-TianjinTangshan economic region and the Yangtze River Delta during long-distance transport (red line in Fig. 6).

3. A heavy dust event occurred at Lin'an on 10 March (approximately from 02:00) according to satellite information (https://earthdata.nasa.gov/labs/worldview/) and meteorology information (provided by the China Meteorological Administration, CMA). The $72 \mathrm{~h}$ back trajectory shows the air masses tracked from Mongolia and passed over Inner Mongolia (blue line in Fig. 6). 


\subsubsection{Locally polluted periods}

During the periods of 4-9, 15-20, and 26-30 March 2013, aerosols were mainly from local pollution sources in Zhejiang and/or nearby provinces. The mean $f(80 \%)$ and $f(85 \%)$ were 1.36 and 1.52 (as shown in Table 4$), \sim 10$ and $8 \%$ lower than those in northerly polluted periods.

The enhancement factor for scattering and backscattering coefficients at $80 \%$ during locally polluted periods was 1.36 and 1.15 , respectively, similar to the values $(f(82.5 \%)=$ $1.4-1.5)$ and $\left(f_{\beta}(82.5 \%)=1.1-1.2\right)$ obtained by KoloutsouVakakis et al. (2001) at a continental US site (Bondville, Illinois, USA). The measured dry scattering coefficient was $217 \mathrm{M} \mathrm{m}^{-1}, \sim 15 \%$ lower than that of the northerly polluted period $\left(251 \mathrm{M} \mathrm{m}^{-1}\right)$. The averaged mass percentages of sulfate, nitrate, ammonium, OM, chloride, and EBC were 17.6, 16.1, 13.0, 42.2, 1.5 and 9.6\%, respectively (Fig. 6a); for this and subsequent calculations of mass percentages, the denominator is the sum of the mass concentrations of sulfate, nitrate, ammonium, OM, chloride, and EBC. Compared to the northerly polluted period, the mass percentage of OM was $\sim 27 \%$ higher during the locally polluted period, while the mass percentage of nitrate was $\sim 33 \%$ lower. Although the $\mathrm{OM} /\left(\mathrm{OM}+\mathrm{SO}_{4}^{2-}\right)$ ratios during locally polluted $(\sim 0.70)$ and northerly polluted periods $(\sim 0.67)$ were similar, the $\mathrm{OM} /\left(\mathrm{OM}+\mathrm{NO}_{3}^{-}+\mathrm{SO}_{4}^{2-}\right)$ ratio during the locally polluted periods $(\sim 0.56)$ was $24 \%$ higher than that during the northerly polluted periods $(\sim 0.45)$, which may partly explain the lower $f(\mathrm{RH})$ during locally polluted episodes (as discussed later in Sect. 3.5).

\subsubsection{Northerly polluted periods}

The air masses reaching Lin'an during the periods $1-3,11-$ 15, 20-26, and 30-31 March (dust episode excluded) mainly came from northern China through long-distance transport. The mean $f(80 \%)$ and $f(85 \%)$ were 1.50 and 1.64 , respectively (as shown in Table 4).

The value $(f(80 \%)=1.50)$ is similar to the previous results $(f(80 \%)=1.48)$ obtained by Yan et al. (2009) for periods influenced by the urban plume from Beijing, $(f(80 \%)=1.46 \pm 0.10)$ reported by Carrico et al. (2000) for anthropogenic aerosols in Europe during ACE-2, and $(f(80 \%)=1.55-1.59)$ indicated by Pan et al. (2009) for a rural site (Xin'an) near Beijing during pollution periods. However, the measured $f(80 \%)$ was much lower than $(f(80 \%)=2.0-2.43)$ during a pollution episode reported by Kim et al. (2006) at the Gosan regional background site, $720 \mathrm{~km}$ northeast of Lin'an, and results $(f(82 \%)=2.24 \pm 0.20)$ obtained by Carrico et al. (2003) in ACE-Asia for polluted air masses measured over the ocean. The $f(\mathrm{RH})$ of continental air masses transported over the ocean was higher than that over the continent, and the possible mechanisms for that increase might include coagulation with sea-salt particles and the oxidation of $\mathrm{SO}_{2}$ and
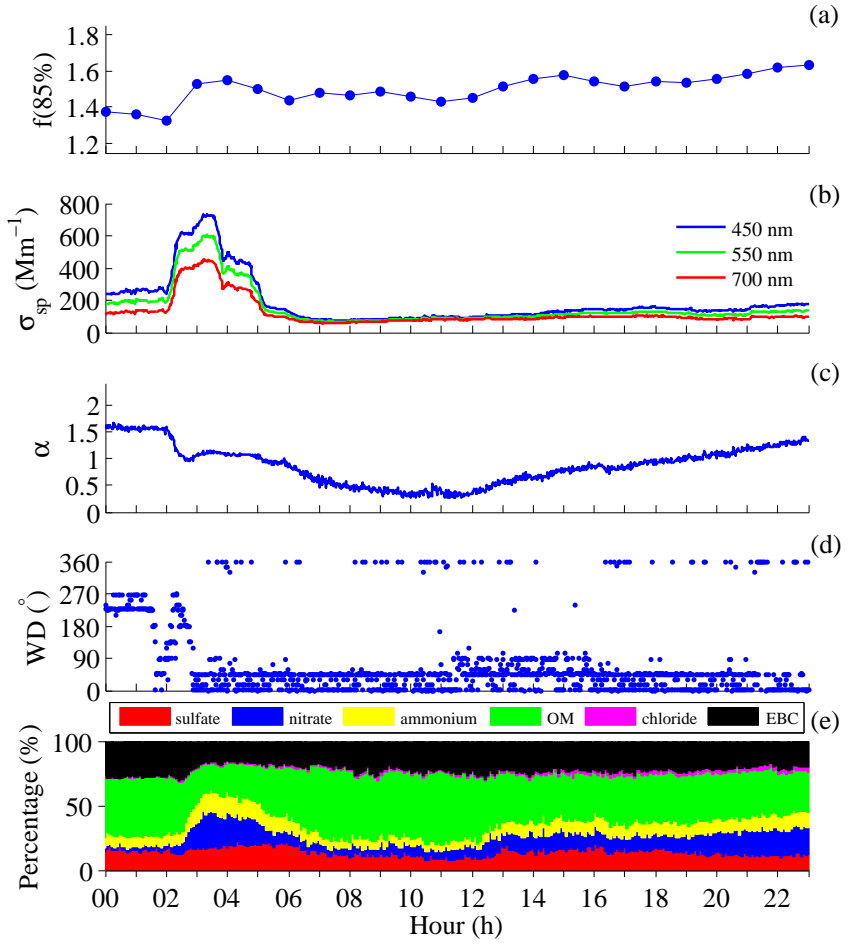

Figure 7. Parameters in an episode influenced by dust on 10 March 2013 at Lin' an (a) scattering enhancement factor $f(85 \%)$ at $550 \mathrm{~nm}$ wavelength; (b) scattering coefficients at 450, 550, and $700 \mathrm{~nm}$ wavelengths; (c) Ångström exponent $\alpha$; (d) wind direction; (e) mass percentages of chemical species measured by AMS and MAAP.

VOCs (volatile organic compounds) leading to an increase in aerosol hygroscopicity.

\subsubsection{Dust-influenced episode}

During a severe cold air outbreak, a strong dust event struck northern China on 8 and 9 March 2013. The affected area covered about 2.8 million square kilometers, about $10 \%$ of which suffered from dust storms or strong sandstorms. This event was considered to be the largest and strongest dust event to hit China in 2013. During this event, suspended dust appeared in most of northwestern China, northern China, north and west Huanghuai region, and west Liaoning Province, while west-central Inner Mongolia, west Gansu, northern Shanxi, and several parts of Xinjiang experienced a sandstorm. Along with the extreme dust event, there was a dramatic increase in $\mathrm{PM}_{10}$, for example, the $\mathrm{PM}_{10}$ in Yulin, Shanxi, even reached $10000 \mu \mathrm{g} \mathrm{m}^{-3}$ (Wang et al., 2013; Zhang and Sun, 2013).

At 02:00 on 10 March, the wind direction changed abruptly to northerly (see Fig. 8d) and the scattering coefficient increased abruptly from $\sim 200$ to $>600 \mathrm{M} \mathrm{m}^{-1}$ (Fig. 7b). $\mathrm{PM}_{10}$ mass concentrations at Lin'an increased rapidly from 100 to $637 \mu \mathrm{g} \mathrm{m}^{-3}$, while the $\mathrm{PM}_{2.5}$ mass 
concentration was only $190 \mu \mathrm{g} \mathrm{m}^{-3}$, accounting for $30 \%$ of $\mathrm{PM}_{10}$. The Ångström exponent decreased from 1.2 to 0.8 (see Fig. 7c). All these phenomena implied the arrival of cold front from northern China enriched in coarsemode particles. The mass percentage of nitrate increased significantly and reached its peak $(\sim 26 \%)$ at 03:00; meanwhile, the mass percentage of OM decreased sharply from 2 to 03:00 (see Fig. 7e). Correspondingly, the scattering enhancement factor $f(85 \%)$ reached 1.52 at 03:00. (see Fig. 7a), an increase of $\sim 16 \%$ compared with that before the dust arrival. During the most dust-dominated period, from 07:00 to 13:00, when the Ångström exponent was below 0.5 (Fig. 7c) and scattering coefficients at 450, 550, and $700 \mathrm{~nm}$ (Fig. $7 \mathrm{~b}$ ) were nearly equal, the scattering enhancement factor $f(85 \%)$ was $\sim 1.46$. This value is much higher than the results $(f(80 \%)=1.20)$ reported by Pan et al. (2009) in rural Beijing, $(f(82.5 \%)=1.18)$ obtained by Carrico et al. (2003) in East Asia (ACE-Asia) during a dust episode, $(f(80 \%)=1.20)$ reported by Fierz-Schmidhauser et al. (2010) at a high alpine site (Jungfraujoch, $3580 \mathrm{~m}$ a.s.l.) in Switzerland during a strong Saharan dust event, and $(f(80 \%)=1.0-1.1)$ measured by Li-Jones et al. (1998) in South America during an investigation of long-range transported Saharan dust. Additionally, it is much lower than the value $(f(85 \%)=1.73-2.20)$ obtained by Kim et al. (2006) in Gosan (South Korea) during a dust-dominated period. According to Tobo et al. (2010), Ca-rich particles can react with gaseous $\mathrm{HNO}_{3}$ to form $\mathrm{Ca}\left(\mathrm{NO}_{3}\right)_{2}$, thus liquid cloudnucleating ability would be enhanced. Similar results have also reported that aerosol hygroscopicity would be largely enhanced if coarse-mode Ca-rich particles combined with nitrate (Shi et al., 2008; Sullivan et al., 2009). Thus, it is speculated that the relatively high $f(\mathrm{RH})$ may have resulted from the reactions of coarse-mode particles with inorganics (very likely to be nitrate) during long-range transport.

\subsection{The relationship of scattering enhancement factor with chemical composition}

Scattering enhancement factor $f(85 \%)$ versus organic mass fraction and inorganic mass fraction are shown in Fig. 8. The total mass concentration was calculated as the sum of mass concentrations of sulfate, nitrate, ammonium, chloride, and OM measured by AMS and EBC measured by MAAP. The organic and inorganic mass fractions were calculated by dividing the mass concentration of organics (measured by AMS) and inorganics (the sum of sulfate, nitrate, ammonium and chloride measured by AMS) by the total mass concentration, respectively. The bivariate linear regression was applied with the uncertainty of $f(85 \%, 550 \mathrm{~nm})$ which was discussed in Sect. 2.4 and the standard deviation of chemical compositions. The bivariate linear regressions (Fig. 8) clearly show anti-correlation of $f(85 \%, 550 \mathrm{~nm})$ with the organic fraction and strong positive correlation of $f(85 \%, 550 \mathrm{~nm})$ with the inorganic fraction. This implies that chemical com-

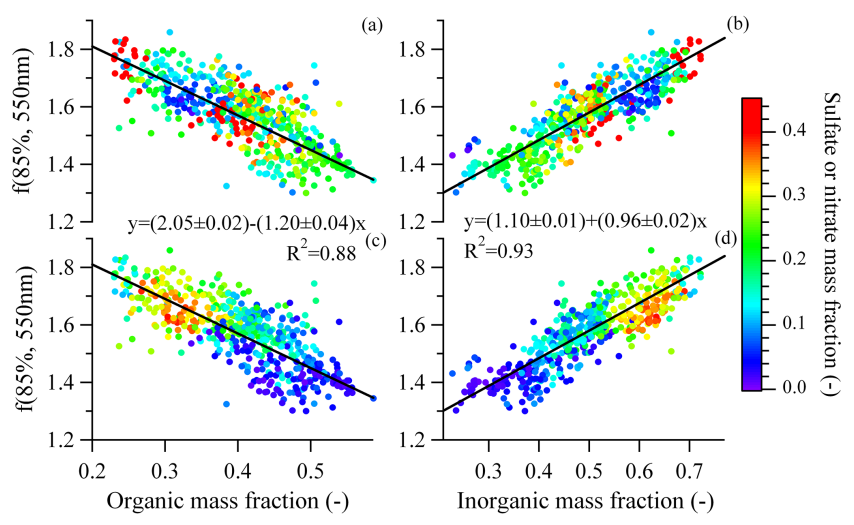

Figure 8. Scattering enhancement factor $f(85 \%, 550 \mathrm{~nm})$ vs. organic mass fraction and inorganic mass fraction determined from AMS and MAAP: (a, b) $f(85 \%, 550 \mathrm{~nm})$ vs. organic mass and inorganic mass fraction colored by sulfate mass fraction; (c, d) $f(85 \%, 550 \mathrm{~nm})$ vs. organic mass fraction and inorganic mass fraction colored by nitrate mass fraction. The solid black line represent a bivariate linear regression including the uncertainty of $f(85 \%$, $550 \mathrm{~nm})$ and the standard deviation of chemical compositions.

position plays a vital role in aerosol hygroscopic properties. The absolute values of both slopes $(1.2$ for $f(85 \%)$ vs. organic mass fraction and 0.96 for $f(85 \%)$ vs. inorganic mass fraction) were much lower than those (3.1 and 2.2, respectively) measured at Melpitz, Germany (Zieger et al., 2014). This may partly be due to the higher organic (or lower inorganic) content at Lin'an. Comparing Fig. 8a and b with Fig. $\mathrm{c}$ and $\mathrm{d}$, a stronger association of increasing nitrate with increasing $f(85 \%)$ was observed. The role nitrate plays in aerosol hygroscopic properties will be discussed in the following paragraph.

$f(\mathrm{RH})$ in Fig. 9 was expressed in terms of $\gamma$ so as to be applied to a broader RH range (Doherty et al., 2005; Quinn et al., 2005): $\gamma=\ln f(\mathrm{RH}) / \ln \left(\left(100-\mathrm{RH}_{\mathrm{ref}}\right) /(100-\mathrm{RH})\right)$. Here $\gamma$ was based on $\mathrm{RH}_{\text {ref }}=40 \%$ and $\mathrm{RH}=85 \%$. The relative amount of $\mathrm{OM}$ and inorganics can be expressed as $\mathrm{Fo}=\mathrm{Cc} /\left(\mathrm{Cc}+\mathrm{C}_{i}\right)$, where $\mathrm{Cc}$ and $\mathrm{C}_{i}$ are the mass concentrations of $\mathrm{OM}$ and inorganics, respectively. Figure 9 shows $\gamma$ versus Fo where $\mathrm{C}_{i}$ was the mass concentrations of $\mathrm{SO}_{4}^{2-}$, $\mathrm{NO}_{3}^{-}$, and $\mathrm{NO}_{3}^{-}+\mathrm{SO}_{4}^{2-}$ in Fig. 9a, b, and c, respectively. For all three scatter plots, there is a trend of decreasing $\gamma$ with increasing Fo. However, unlike the results of Quinn et al. (2005), Malm et al. (2005), Pan et al. (2009), and Yan et al. (2009), $\gamma$ and $\mathrm{Fo}\left(\mathrm{OM} /\left(\mathrm{OM}+\mathrm{SO}_{4}^{2-}\right)\right)$ (Fig. 9a) were uncorrelated $\left(R^{2}=0.14\right)$, while $\gamma$ and $\mathrm{Fo}\left(\mathrm{OM} /\left(\mathrm{OM}+\mathrm{NO}_{3}^{-}\right)\right)$ (Fig. 9b) and $\gamma$ and Fo $\left(\mathrm{OM} /\left(\mathrm{OM}+\mathrm{SO}_{4}^{2-}+\mathrm{NO}_{3}^{-}\right)\right)$(Fig. 9c) were more strongly correlated $\left(\mathrm{R}^{2}\right.$ of 0.56 and 0.68 , respectively). This result implies that $\mathrm{NO}_{3}^{-}$played a stronger role in determining aerosol hygroscopic growth than $\mathrm{SO}_{4}^{2-}$ during this study. This increasing importance of nitrate corresponds to many recent studies in Shanghai (a megacity in the 


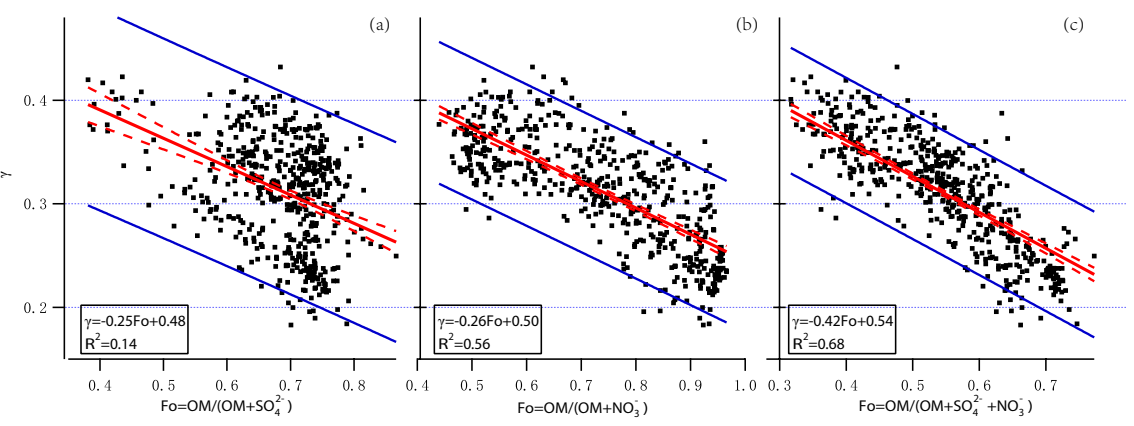

Figure 9. Scatter plots of $\gamma$ versus the relative amount of $\mathrm{OM}$ and inorganics $(\mathrm{Fo})(\mathbf{a}) \mathrm{Fo}=\mathrm{OM} /\left(\mathrm{OM}+\mathrm{SO}_{4}^{2-}\right),(\mathbf{b}) \mathrm{Fo}=\mathrm{OM}^{-}\left(\mathrm{OM}_{+} \mathrm{NO}-{ }_{3}^{-}\right)$, and (c) $\mathrm{Fo}=\mathrm{OM} /\left(\mathrm{OM}+\mathrm{SO}_{4}^{2-}+\mathrm{NO}_{3}^{-}\right)$. Solid red lines represent the linear fit, dashed red lines show the $95 \%$ confidence level for the fit, and solid blue lines show the $95 \%$ prediction bands.

Yangtze River Delta) (Shi et al., 2014) and Beijing (Sun et al., 2012). This may partly result from the increasing availability of $\mathrm{NH}_{3}$ to form $\mathrm{NH}_{4} \mathrm{NO}_{3}$ (Morgan et al., 2010) due to the decrease of $\mathrm{SO}_{2}$. The Chinese government has put an emphasis on the control of $\mathrm{SO}_{2}$ emissions in recent years, and desulfurization technology has been installed at coal-fired power units as well as certain steel and cement production facilities. As a result, the annual average concentration of $\mathrm{SO}_{2}$ decreased significantly from 56 to $19 \mu \mathrm{g} \mathrm{m}^{-3}$ at Lin'an from 2006 to 2012 (ZEPB, 2012, 2006).

The molar ratio of particulate $\mathrm{SO}_{4}^{2-}$ to total sulfur $\left(\mathrm{SO}_{4}^{2-}+\right.$ gas-phase $\mathrm{SO}_{2}$ ) was used as an indicator of the relative age of aerosols (Quinn et al., 2005). For relatively younger aerosols, there is insufficient time for the conversion of $\mathrm{SO}_{2}$ to $\mathrm{SO}_{4}^{2-}$ via gas- and aqueous-phase oxidation processes and therefore the $\mathrm{SO}_{4}^{2-} /\left(\mathrm{SO}_{4}^{2-}+\mathrm{SO}_{2}\right)$ molar ratio is low. As aerosol ages, more $\mathrm{SO}_{2}$ is converted to $\mathrm{SO}_{4}^{2-}$ and thus the ratio increases. To illustrate the effects of this ratio and scattering coefficient on $\gamma$, Fig. 10 shows $\gamma$ versus $\mathrm{Fo}=\mathrm{OM} /(\mathrm{OM}+$ $\left.\mathrm{SO}_{4}^{2-}+\mathrm{NO}_{3}^{-}\right)$colored by the $\mathrm{SO}_{4}^{2-} /\left(\mathrm{SO}_{4}^{2-}+\mathrm{SO}_{2}\right)$ molar ratio (Fig. 10a) and $\log _{10}\left(\sigma_{\mathrm{sp}}\right)$ (Fig. 10b). The highest values of $\gamma$ (or $f(\mathrm{RH}))$ corresponded to more aged aerosols with a low OM content, while the lowest values corresponded to younger aerosols with a higher OM content, consistent with the result of Quinn et al. (2005). For aerosols with relatively low scattering coefficients, the value of $f(\mathrm{RH})$ was usually low with a large variation (dots with cooler colors in Fig. 10b), while aerosols with high scattering coefficients had values of $f(\mathrm{RH})$ that were relatively high with a small variation (dots with warm colors in Fig. 10b).

\subsection{Parameterization of scattering enhancement factor $f(\mathbf{R H})$}

The scattering enhancement factor $f(\mathrm{RH})$ can be parameterized with empirical equations (Kotchenruther and Hobbs, 1998; Kotchenruther et al., 1999; Gassó et al., 2000; Carrico et al., 2003; Liu et al., 2008; Pan et al., 2009; Zieger et al., 2010; Zieger et al., 2014). Humidograms from Lin'an were
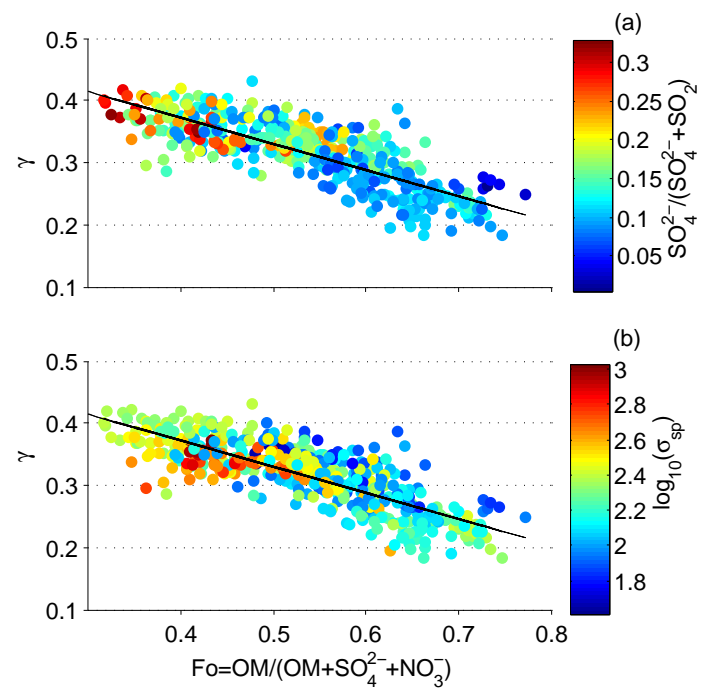

Figure 10. $\gamma$ versus $\mathrm{Fo}=\mathrm{OM} /\left(\mathrm{OM}+\mathrm{SO}_{4}^{2-}+\mathrm{NO}_{3}^{-}\right)$colored by (A) $\mathrm{SO}_{4}^{2-} /\left(\mathrm{SO}_{4}^{2-}+\mathrm{SO}_{2}\right)$ molar ratio and (b) $\log _{10}\left(\sigma_{\mathrm{sp}}\right)$.

fitted with two empirical equations and the fitting results are shown below.

\subsubsection{Parameterization with equation $f(\mathbf{R H})=c \times(1-\mathbf{R H})^{-g}$}

Kasten (1969) proposed an empirical equation $f(\mathrm{RH})=c \times$ $(1-\mathrm{RH})^{-g}$ to describe how $f(\mathrm{RH})$ varies with $\mathrm{RH}$, which has been used in previous reports, e.g., by Kotchenruther and Hobbs (1998), Gassó et al. (2000), Carrico et al. (2003), and Zieger et al. (2010, 2014). Table 5 shows the fitting results from the current work and previous studies. Larger $f(\mathrm{RH})$ values are associated with larger values of " $c$ " and " $g$ ". In this work, $g$ was much lower than that in most of the other studies, although it was similar to the result of Gassó et al. (2000) during a dust episode. The similarity results from the low scattering enhancement factor (e.g., $f(80 \%)=1.44 \pm 0.12$ ) at Lin'an, which was similar 
Table 5. Curve-fitting parameters of $f(\mathrm{RH})$ at $550 \mathrm{~nm}$ wavelength for various aerosol types using equation $f(\mathrm{RH})=c \times(1-\mathrm{RH})^{-g}$.

\begin{tabular}{lccl}
\hline & $c$ & $g$ & Reference \\
\hline Locally polluted & $0.85 \pm 0.08$ & $0.29 \pm 0.04$ & \\
Northerly polluted & $0.93 \pm 0.07$ & $0.28 \pm 0.03$ & This work \\
Dust-influenced & $0.87 \pm 0.05$ & $0.27 \pm 0.02$ & \\
\hline Continental & 0.9 & 0.59 & Zieger et al. (2014) \\
\hline Arctic $^{\mathrm{a}}$ & 1 & $0.58 \pm 0.09$ & Zieger et al. (2010) \\
\hline Marine & 0.99 & 0.54 & \\
Polluted & 0.59 & 0.77 & Carrico et al. (2003) \\
Dust & 0.60 & 0.61 & \\
\hline Polluted marine & 1 & $0.57 \pm 0.06$ & Gassó et al. (2000) \\
Dust & 1 & $0.23 \pm 0.05$ & \\
Clean marine $^{\mathrm{b}}$ & 1 & $0.69 \pm 0.06$ & \\
Clean marine2 $^{\mathrm{c}}$ & 1 & $0.73 \pm 0.07$ & \\
\hline
\end{tabular}

${ }^{\mathrm{a}}$ fitting results for aerosol samples with $\mathrm{RH}>75 \%{ }^{\mathrm{b}}$ fitting results for aerosol samples with $\mathrm{RH}>60 \%{ }^{\mathrm{c}}$ fitting results for aerosol samples with $\mathrm{RH}>80 \%$.

to the value $(f(80 \%)=1.33 \pm 0.07)$ obtained by Gassó et al. (2000) for a dust event. The $f(\mathrm{RH})$ in other studies was much higher than that at Lin'an, ranging from 2.04 (polluted marine aerosols in Gassó et al., 2000) to 3.77 (arctic aerosols in Zieger et al., 2010), and therefore their parameter $g$ was much higher.

\subsubsection{Parameterization with equation $f(\mathbf{R H})=1+a \times \mathbf{R H}^{b}$}

The $f(\mathrm{RH})$ obtained at Lin'an station can also be well described by the following equation, which was proposed by Kotchenruther and Hobbs (1998):

$f(\mathrm{RH})=1+a \times \mathrm{RH}^{b}$,

where " $a$ " is positive and " $b$ " is greater than 1 . This function is convex, and has been used in many previous studies (Pan et al., 2009; Carrico et al., 2003; Kotchenruther et al., 1999; Kotchenruther and Hobbs, 1998) to describe monotonic growth. Theoretically, parameter $a$ determines the largest value $f(100 \%)$ can reach, and parameter $b$ dominates the curvature of the function. The smaller $b$ is, the smaller the curvature of humidogram will be; if $b$ equals 1 , then $f(\mathrm{RH})=1+a \times \mathrm{RH}$. The parameters $a$ and $b$ from our study and previous results for different aerosol types are listed in Table 6 . Taking the locally polluted episode as an example, although parameter $a$ is slightly larger $(\sim 3 \%)$ than in the northerly polluted episode, parameter $b$ is $\sim 40 \%$ larger; as a result the $f(85 \%)$ during locally polluted periods is smaller. Parameter $b$ is greatest in the locally polluted episode and smallest in the northerly polluted period, i.e., the curvature of the RH- $f(\mathrm{RH})$ line is largest during the locally polluted episode, smaller in the dust episode, and the northerly polluted period shows the least curvature. These variations in curvature are associated with the mass percentages of nitrate, as will be discussed later (see Fig. 6).
Table 6. Curve-fitting parameters of $f(\mathrm{RH})$ at 550nm wavelength for various aerosol types in terms of Eq. (5).

\begin{tabular}{lccl}
\hline & $a$ & $b$ & Reference \\
\hline Locally polluted & $1.24 \pm 0.29$ & $5.46 \pm 1.90$ & \\
Northerly polluted & $1.20 \pm 0.21$ & $3.90 \pm 1.27$ & This work \\
Dust-influenced & $1.02 \pm 0.19$ & $4.51 \pm 0.80$ & \\
\hline Clean & $1.20 \pm 0.06$ & $6.07 \pm 0.27$ & \\
Polluted & $2.30 \pm 0.03$ & $6.27 \pm 0.10$ & Pan et al. (2009) \\
Dust & $0.64 \pm 0.04$ & $5.17 \pm 0.40$ & \\
\hline Urban & 2.06 & 3.60 & \\
Mixed & 3.26 & 3.85 & Liu et al. (2007) \\
Marine & 4.92 & 5.04 & \\
\hline
\end{tabular}
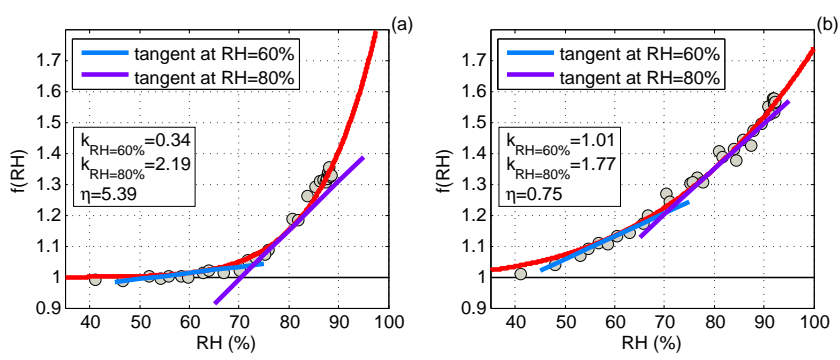

Figure 11. Two distinct examples showing different growth patterns and the corresponding $\eta$ (a) 8 March 2013, 18:00 $f(\mathrm{RH})$ increased slowly at low RH (usually $<70 \%$ ) and then increase more steeply, thus $\eta$ is big; (b) 10 March 2013, 21:00 $f(\mathrm{RH})$ increased at a nearly constant rate and $\eta$ is small. $k_{\mathrm{RH}}=60 \%$ and $k_{\mathrm{RH}}=80 \%$ represent the derivatives at 60 and $80 \% \mathrm{RH}$, respectively. $f(\mathrm{RH})$ given at $550 \mathrm{~nm}$ wavelength.

\subsubsection{Steepness of humidograms}

For all the humidograms measured at Lin'an, $f(\mathrm{RH})$ increases continuously and monotonically. However, the curvatures of the humidograms are different (Fig. 11); some increase with a nearly constant rate and the humidogram curve is almost straight, while some increase slowly at first and then increase more steeply at relatively higher RH, thus the curvature of the humidogram is larger. In order to describe the growth pattern quantitatively, a steepness index $\eta$ is defined based on the fitting curve:

$\eta=f^{\prime}(80 \%) / f^{\prime}(60 \%)-1=(4 / 3)^{b-1}-1$,

where $f^{\prime}(60 \%)$ and $f^{\prime}(80 \%)$ represent the derivatives of the fitting curve at $60 \%$ and $80 \% \mathrm{RH}$, respectively. $\eta$ is a nonnegative number. Zieger et al. (2010) has defined an index describing the magnitude of deliquescence transitions based on fitting equation $f(\mathrm{RH})=(1-\mathrm{RH})^{-g}$ (see Sect. 3.6.1), while the steepness index $\eta$ proposed in this study provided a way of quantitatively describing the steepness of humidograms that are well described by the equation $f(\mathrm{RH})=1+a \times \mathrm{RH}^{b}$. The larger $\eta$ is, the greater the curvature. As is shown in Fig. $11 \mathrm{a}$, for a large $\eta$, the $f^{\prime}(60 \%)$ is very small, meaning 


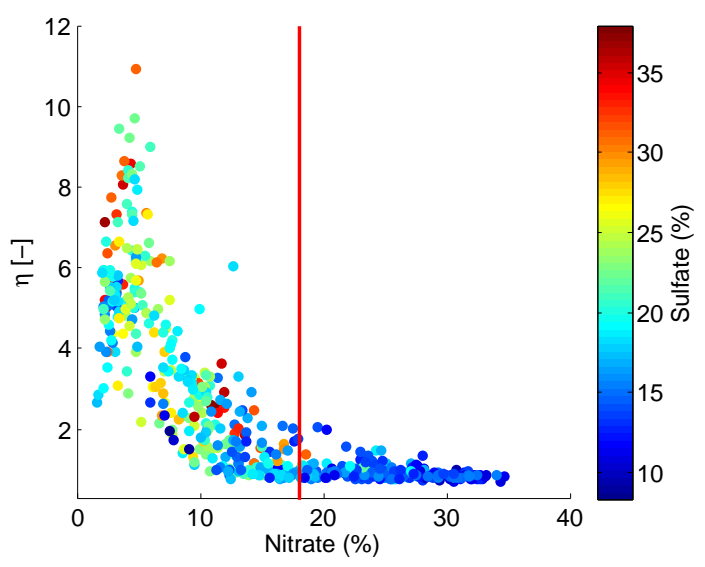

Figure 12. Scatter plot of $\eta$ and the mass percentage of nitrate, colored by the mass percentage of sulfate.

that aerosol scattering coefficient barely increases $(f(\mathrm{RH}) \approx$ 1) under low RH (usually $<70 \%$ ). Once reaching larger RH ( $70 \%), f(\mathrm{RH})$ begins to increase. However, for a small $\eta$ (Fig. 11b), the difference of the derivatives at 60 and $80 \%$ $\mathrm{RH}$ was small, meaning the curvature of humidogram is much smaller.

A scatter plot of $\eta$ and the mass percentage of nitrate is shown in Fig. 12, colored by the mass percentage of sulfate. As can be seen, $\eta$ is negatively correlated with the mass percentage of nitrate. When the mass percentage of nitrate is below $\sim 18 \%, \eta$ decreases strongly as nitrate percentages increase, which means that the humidogram line becomes straighter and the difference of the derivatives at lower and higher RHs becomes smaller. For a mass percentage of nitrate higher than $18 \%$ (correspondingly, a lower sulfate mass percentage), $\eta$ is $\sim 1.1$, meaning the humidogram line is almost straight (as shown in Fig. 11b) and aerosol scattering coefficient experiences a continuous and smooth growth at almost the same rate with $\mathrm{RH}$.

\subsection{Sensitivity of the direct radiative forcing of different aerosols to $f(\mathbf{R H})$}

Direct radiative forcing of aerosols is quite sensitive to changes of relative humidity. The impact of relative humidity on globally averaged, direct radiative forcing can be obtained by the following expression (Chylek and Wong, 1995):

$$
\begin{gathered}
\Delta F_{\mathrm{R}}(\mathrm{RH})=-\left[S_{0} / 4\right]\left[T_{\mathrm{a}}^{2}\left(1-A_{\mathrm{c}}\right)\right]\left[2\left(1-R_{\mathrm{s}}\right)^{2}\right. \\
\left.\bar{\beta}(\mathrm{RH}) M \alpha_{\mathrm{s}} f(\mathrm{RH})-4 R_{\mathrm{S}} M \alpha_{\mathrm{a}}\right],
\end{gathered}
$$

where $S_{0}$ is the solar constant, $T_{\mathrm{a}}$ is the transmittance of the atmosphere above the aerosol layer, $A_{\mathrm{c}}$ is the fractional cloud amount, $R_{\mathrm{S}}$ is the albedo of the underlying surface, $\bar{\beta}(\mathrm{RH})$ is the solar radiation scattered back to space at defined $\mathrm{RH}$, $f(\mathrm{RH})$ is the scattering enhancement factor, $M$ is the column burden of aerosol (in $\mathrm{g} \mathrm{m}^{-2}$ ), $\alpha_{\mathrm{s}}$ is the mass scattering efficiency, and $\alpha_{\mathrm{a}}$ is the mass absorption efficiency.

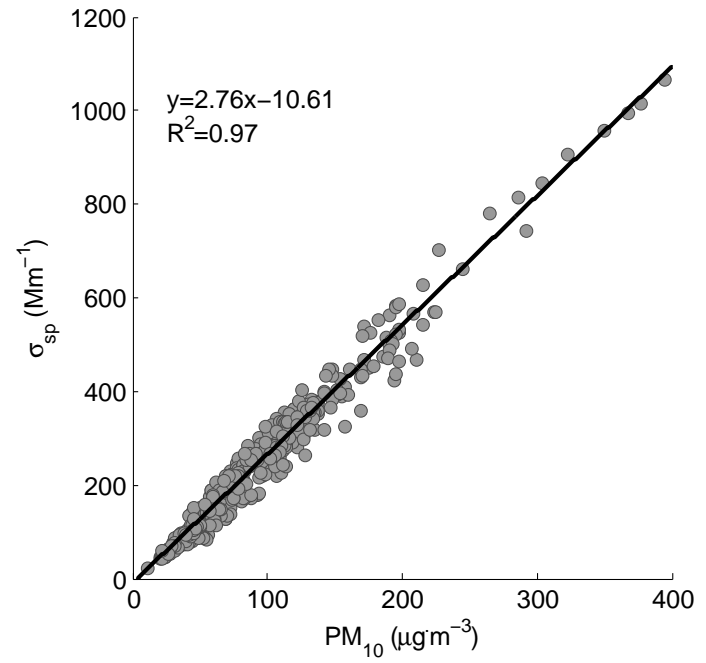

Figure 13. Linear regression of scattering coefficients $\left(\sigma_{\mathrm{sp}}\right)$ at $550 \mathrm{~nm}$ wavelength and $\mathrm{PM}_{10}$ mass concentration.

In order to estimate the sensitivity of the forcing to RH for various aerosol types at Lin'an (locally polluted, northerly polluted, and dust-influenced aerosols), the ratio of direct aerosol radiative forcing $\Delta F_{\mathrm{R}}$ at a defined $\mathrm{RH}$ to that at dry conditions was calculated:

$$
\frac{\Delta F_{\mathrm{R}}(\mathrm{RH})}{\Delta F_{\mathrm{R}}(\text { dry })}=\frac{\left(1-R_{\mathrm{S}}\right)^{2} \bar{\beta}(\mathrm{RH}) \alpha_{\mathrm{s}} f(\mathrm{RH})-2 R_{\mathrm{S}} \alpha_{\alpha}}{\left(1-R_{\mathrm{S}}\right)^{2} \bar{\beta}(\text { dry }) \alpha_{\mathrm{s}} f(\text { dry })-2 R_{\mathrm{S}} \alpha_{\alpha}} .
$$

Parameters used in Eq. (8) were $R_{\mathrm{S}}=0.15$, and $\alpha_{\mathrm{a}}=$ $0.3 \mathrm{~m}^{2} \mathrm{~g}^{-1}$ (Wang et al., 2012; Hand and Malm, 2007). The mass scattering efficiency $\alpha_{\mathrm{s}}$ is $2.76 \mathrm{~m}^{2} \mathrm{~g}^{-1}$, which is derived from the slope of a linear regression of the measured scattering coefficients and the calculated $\mathrm{PM}_{10}$ mass concentrations based on TDMPS and APS measurement (Fig. 13); the high mass scattering efficiency is explained by the high ratio of $\mathrm{PM}_{1}$ to $\mathrm{PM}_{10}$ mass at this site (average 0.81). The average upscatter fraction $\bar{\beta}$ was calculated as $\bar{\beta}=0.0817+$ $1.8495 b-2.9682 b^{2}$ (Delene and Ogren, 2002). The sensitivity of direct radiative forcing to $\mathrm{RH}$ for various aerosol types is shown in Fig. 14. As is shown in the figure, the variation of $\Delta F_{0} R(\mathrm{RH}) / \Delta F_{\mathrm{R}}$ (dry) with $\mathrm{RH}$ corresponds to the variation of humidograms. The $f(\mathrm{RH})$ values were the largest during the northerly polluted period and, correspondingly, the effect of $\mathrm{RH}$ on aerosol radiative forcing during this period was the largest. The same was true for the locally polluted period and the dust-influenced period. Since $\bar{\beta}$ decreases with increasing $\mathrm{RH}$, this correspondence also demonstrates the vital role $f(\mathrm{RH})$ plays in direct forcing enhancement. At $85 \% \mathrm{RH}$, the average ratio was 1.47 , i.e., the direct radiative forcing increased by $47 \%$ owing to the aerosol hygroscopicity.

Table 7 shows the mean influence of aerosol hygroscopicity on direct radiative forcing in March at Lin'an. The ratios $\Delta F_{\mathrm{R}}\left(\mathrm{RH}_{\mathrm{amb}}\right) / \Delta F_{\mathrm{R}}(\mathrm{dry})$ for locally polluted, northerly polluted, and dust-influenced aerosols were cal- 
Table 7. Estimated effects of aerosol hygroscopic growth on direct radiative forcing by locally polluted, northerly polluted, and dustinfluenced aerosols at Lin'an, measured by the ratio $\left(\Delta F_{\mathrm{R}}\left(\mathrm{RH}_{\mathrm{amb}}\right) / \Delta F_{\mathrm{R}}(\right.$ dry $\left.)\right)$ of direct aerosol radiative forcing at the ambient average relative humidity $\left(\mathrm{RH}_{\mathrm{amb}}=67 \%\right)$ for the entire campaign to that in dry conditions. All the parameters were measured at $550 \mathrm{~nm}$ wavelength.

\begin{tabular}{lcccccc}
\hline & $f\left(\mathrm{RH}_{\mathrm{amb}}\right)$ & $b(\mathrm{dry})$ & $\bar{\beta}(\mathrm{dry})$ & $b\left(\mathrm{RH}_{\mathrm{amb}}\right)$ & $\bar{\beta}\left(\mathrm{RH}_{\mathrm{amb}}\right)$ & $\Delta F_{\mathrm{R}}\left(\mathrm{RH}_{\mathrm{amb}}\right) / \Delta F_{\mathrm{R}}(\mathrm{dry})$ \\
\hline Entire campaign & 1.21 & 0.126 & 0.268 & 0.115 & 0.255 & 1.157 \\
Locally polluted & 1.17 & 0.131 & 0.274 & 0.123 & 0.263 & 1.118 \\
Northerly polluted & 1.26 & 0.121 & 0.262 & 0.106 & 0.243 & 1.195 \\
Dust-influenced & 1.15 & 0.146 & 0.289 & 0.132 & 0.274 & 1.105 \\
\hline
\end{tabular}

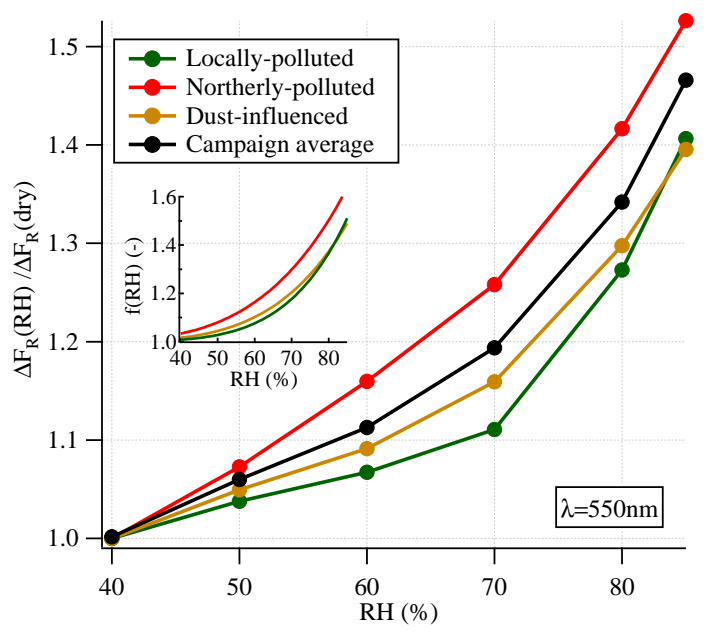

Figure 14. Influence of relative humidity $(\mathrm{RH})$ on direct radiative forcing for the entire campaign (black line), as well as for the northerly polluted, locally polluted, and dust-polluted periods, measured by the ratio of radiative forcing at a certain $\mathrm{RH}$ to that at dry conditions. The small inlay shows the fitting curves of $f(\mathrm{RH})$ for northerly polluted, locally polluted, and dust-polluted periods using fitting parameters in Table 6. All the parameters were measured at $550 \mathrm{~nm}$ wavelength.

culated using the ambient average $\mathrm{RH}\left(\mathrm{RH}_{\mathrm{amb}}=67 \%\right)$ in March at Lin'an. The variables $f\left(\mathrm{RH}_{\mathrm{amb}}\right), b\left(\mathrm{RH}_{\mathrm{amb}}\right)$, $\bar{\beta}\left(\mathrm{RH}_{\mathrm{amb}}\right)$, and $\Delta F_{\mathrm{R}}\left(\mathrm{RH}_{\mathrm{amb}}\right) / \Delta F_{\mathrm{R}}($ dry $)$ were the averages of the linear interpolation results of $f(\mathrm{RH}), b(\mathrm{RH})$, $\bar{\beta}(\mathrm{RH})$, and $\Delta F_{\mathrm{R}}(\mathrm{RH}) / \Delta F_{\mathrm{R}}$ (dry) to $67 \% \mathrm{RH}$. The $\Delta F_{\mathrm{R}}\left(\mathrm{RH}_{\mathrm{amb}}\right) / \Delta F_{\mathrm{R}}$ (dry) ratios were $1.118,1.195$ and 1.105 , respectively (see Table 7). That is to say, on average, the direct radiative forcing of locally polluted, northerly polluted, and dust-influenced aerosols increased by 11.8, 19.5, and $10.5 \%$ in March at Lin'an.

\section{Conclusions}

The influence of aerosol water uptake on aerosol light scattering properties and direct radiative forcing have been investigated at the Lin'an Regional Atmosphere Background Station in the Yangtze River Delta, China, using a scat- tering enhancement factor measurement system, together with chemical composition and size distribution information. The average enhancement factors and mean standard deviations at $85 \% \mathrm{RH}$ for scattering coefficient, backscattering coefficient, and hemispheric backscatter fraction $(f(85 \%)$, $f_{\mathrm{b}}(85 \%)$ and $\mathrm{f}_{\beta}(85 \%)$ ) were $1.58(0.12), 1.25(0.07)$, and $0.79(0.04)$, respectively. A slight wavelength dependence of $f(85 \%)$ was observed at higher $f(\mathrm{RH})$ values. Generally, the highest values of $f(\mathrm{RH})$ corresponded to aged aerosols with a small fraction of OM, while the lowest values corresponded to younger aerosols with a larger fraction of OM. $f(\mathrm{RH})$ of aerosols with relatively low scattering coefficients was usually low with a large variation, while $f(\mathrm{RH})$ of aerosols with high scattering coefficients was relatively high with a small variation. Nitrate was found to play an important role in determining the magnitude of $f(\mathrm{RH})$ at Lin'an.

Humidograms measured at Lin'an can be well described by two equations: $f(\mathrm{RH})=c \times(1-\mathrm{RH})^{-d}$ and $f(\mathrm{RH})=1+$ $a \times \mathrm{RH}^{b}$. Further investigation shows the shape of the humidogram is closely related to the mass percentage of nitrate. A steepness index $\eta$ has been defined to quantitatively determine the steepness of the humidograms. The least curvature of the humidograms (smallest $\eta$ ) was associated with the highest nitrate mass fractions (and lowest sulfate fractions). In March, the average relative humidity $\left(\mathrm{RH}_{\mathrm{amb}}\right)$ was $67 \%$. Consequently, the direct radiative forcing of locally polluted, northerly polluted, and dust-influenced aerosols increased by $11.8,19.5$, and $10.5 \%$, respectively due to aerosol uptake water in March at Lin'an. At $85 \% \mathrm{RH}$, the direct radiative forcing increased by as much as $47 \%$ due to aerosol hygroscopicity. In conclusion, water plays an important role in aerosol scattering properties as well as radiative forcing, and careful attention to humidity effects is required when comparing remote sensing and in-situ measurements or calculating climate forcing.

Acknowledgements. This work was supported by National Basic Research Program of China (2011CB403401), the National Natural Science Foundation of China (41475118, 41175113), China International Science and Technology Cooperation Project (2009DFA22800), CAMS Basis Research Project (2013Z007, 2013Y004), and the Meteorological Special Project of China (GYHY-200906038, GYHY201206037). This paper is partially 
supported by the CMA Innovation Team for Haze-fog Observation and Forecasts. The authors would also like to thank the Lin'an observational station staff for their support. The authors thank D. Covert of the Department of Atmospheric Sciences, University of Washington Seattle, USA, for useful discussions.

Edited by: U. Baltensperger

\section{References}

Ackerman, A. S., Kirkpatrick, M. P., Stevens, D. E., and Toon, O. B.: The impact of humidity above stratiform clouds on indirect aerosol climate forcing, Nature, 432, 1014-1017, 2004.

Anderson, T., Covert, D., Marshall, S., Laucks, M., Charlson, R., Waggoner, A., Ogren, J., Caldow, R., Holm, R., and Quant, F.: Performance characteristics of a high-sensitivity, threewavelength, total scatter/backscatter nephelometer, J. Atmos. Ocean. Tech., 13, 967-986, 1996.

Anderson, T. L. and Ogren, J. A.: Determining aerosol radiative properties using the TSI 3563 integrating nephelometer, Aerosol Sci. Tech., 29, 57-69, 1998.

Berner, A., Lürzer, C., Pohl, F., Preining, O., and Wagner, P.: The size distribution of the urban aerosol in Vienna, Sci. Total Environ., 13, 245-261, 1979.

Birmili, W., Stratmann, F., and Wiedensohler, A.: Design of a DMA-based size spectrometer for a large particle size range and stable operation, J. Aerosol Sci., 30, 549-553, 1999.

Carrico, C. M., Rood, M. J., and Ogren, J. A.: Aerosol light scattering properties at Cape Grim, Tasmania, during the first Aerosol Characterization Experiment (ACE 1), J. Geophys. Res., 103, 16565-16574, 1998.

Carrico, C. M., Rood, M. J., Ogren, J. A., Neusüß, C., Wiedensohler, A., and Heintzenberg, J.: Aerosol Optical properties at Sagres, Portugal during ACE-2, Tellus B, 52, 694-715, 2000.

Carrico, C. M., Kus, P., Rood, M. J., Quinn, P. K., and Bates, T. S.: Mixtures of pollution, dust, sea salt, and volcanic aerosol during ACE-Asia: Radiative properties as a function of relative humidity, J. Geophys. Res., 108, 8650, doi:10.1029/2003JD003405, 2003.

Charlson, R. J., Ahlquist, N., Selvidge, H., and MacCready Jr., P.: Monitoring of atmospheric aerosol parameters with the integrating nephelometer, JAPCA J. Air Waste Manage., 19, 937-942, 1969.

Charlson, R. J., Schwartz, S., Hales, J., Cess, R. D., Coakley Jr., J. A., Hansen, J., and Hofmann, D.: Climate forcing by anthropogenic aerosols, Science, 255, 423-430, 1992.

Cheng, Y., Wiedensohler, A., Eichler, H., Heintzenberg, J., Tesche, M., Ansmann, A., Wendisch, M., Su, H., Althausen, D., and Herrmann, H.: Relative humidity dependence of aerosol optical properties and direct radiative forcing in the surface boundary layer at Xinken in Pearl River Delta of China: An observation based numerical study, Atmos. Environ., 42, 6373-6397, 2008.

Chylek, P. and Wong, J.: Effect of absorbing aerosols on global radiation budget, Geophys. Res. Lett., 22, 929-931, 1995.

Covert, D. S., Charlson, R., and Ahlquist, N.: A study of the relationship of chemical composition and humidity to light scattering by aerosols, J. Appl. Meteorol., 11, 968-976, 1972.
Day, D. E. and Malm, W. C.: Aerosol light scattering measurements as a function of relative humidity: a comparison between measurements made at three different sites, Atmos. Environ., 35, 5169-5176, 2001.

Delene, D. J. and Ogren, J. A.: Variability of aerosol optical properties at four North American surface monitoring sites, J. Atmos. Sci., 59, 1135-1150, 2002.

Dick, W. D., Saxena, P., and McMurry, P. H.: Estimation of water uptake by organic compounds in submicron aerosols measured during the Southeastern Aerosol and Visibility Study, J. Geophys. Res.-Atmos., 105, 1471-1479, 2000.

Doherty, S. J., Quinn, P. K., Jefferson, A., Carrico, C. M., Anderson, T. L., and Hegg, D.: A comparison and summary of aerosol optical properties as observed in situ from aircraft, ship, and land during ACE-Asia, J. Geophys. Res, 110, D04201, doi:10.1029/2004JD004964, 2005.

Engelhart, G. J., Hildebrandt, L., Kostenidou, E., Mihalopoulos, N., Donahue, N. M., and Pandis, S. N.: Water content of aged aerosol, Atmos. Chem. Phys., 11, 911-920, doi:10.5194/acp-11911-2011, 2011.

Fang, S. X., Zhou, L. X., Masarie, K. A., Xu, L., and Rella, C. W.: Study of atmospheric $\mathrm{CH}_{4}$ mole fractions at three WMO/GAW stations in China, J. Geophys. Res.-Atmos., 118, 4874-4886, 2013.

Fierz-Schmidhauser, R., Zieger, P., Gysel, M., Kammermann, L., DeCarlo, P. F., Baltensperger, U., and Weingartner, E.: Measured and predicted aerosol light scattering enhancement factors at the high alpine site Jungfraujoch, Atmos. Chem. Phys., 10, 23192333, doi:10.5194/acp-10-2319-2010, 2010.

Gasso, S., Hegg, D., Covert, D., Collins, D., Noone, K., Öström, E., Schmid, B., Russell, P., Livingston, J., and Durkee, P.: Influence of humidity on the aerosol scattering coefficient and its effect on the upwelling radiance during ACE-2, Tellus B, 52, 546-567, 2000.

Hand, J. and Malm, W.: Review of aerosol mass scattering efficiencies from ground-based measurements since 1990, J. Geophys. Res.-Atmos., 112, D16203, doi:10.1029/2007JD008484, 2007.

Hänel, G.: The properties of atmospheric aerosol particles as functions of the relative humidity at thermodynamic equilibrium with the surrounding moist air, Adv. Geophys, 19, 73-188, 1976.

Kasten, F.: Visibility forecast in the phase of precondensation, Tellus, 21, 631-635, 1969.

Kim, J., Yoon, S.-C., Jefferson, A., and Kim, S.-W.: Aerosol hygroscopic properties during Asian dust, pollution, and biomass burning episodes at Gosan, Korea in April 2001, Atmos. Environ., 40, 1550-1560, 2006.

Koloutsou-Vakakis, S., Carrico, C., Kus, P., Rood, M., Li, Z., Shrestha, R., Ogren, J., Chow, J., and Watson, J.: Aerosol properties at a midlatitude Northern Hemisphere continental site, J. Geophys. Res., 106, 3019-3032, 2001.

Kotchenruther, R. A. and Hobbs, P. V.: Humidification factors of aerosols from biomass burning in Brazil, J. Geophys. Res., 103, 32081-32089, doi:10.1029/98jd00340, 1998.

Kotchenruther, R. A., Hobbs, P. V., and Hegg, D. A.: Humidification factors for atmospheric aerosols off the mid-Atlantic coast of the United States, J. Geophys. Res., 104, 2239-2251, 1999.

Li-Jones, X., Maring, H. B., and Prospero, J. M.: Effect of relative humidity on light scattering by mineral dust aerosol as measured 
in the marine boundary layer over the tropical Atlantic Ocean, J. Geophys. Res., 103, 31113-31121, 1998.

Liu, X., Zhang, Y., Jung, J., Gu, J., Li, Y., Guo, S., Chang, S.Y., Yue, D., Lin, P., Kim, Y. J., Hu, M., Zeng, L., and Zhu, T.: Research on the hygroscopic properties of aerosols by measurement and modeling during CAREBeijing-2006, J. Geophys. Res.-Atmos, 114, D00G16, doi:10.1029/2008JD010805, 2009.

Magi, B. I. and Hobbs, P. V.: Effects of humidity on aerosols in southern Africa during the biomass burning season, J. Geophys. Res.-Atmos. 108, 8504, doi:10.1029/2002JD002144, 2003.

Malm, W. C. and Day, D. E.: Optical properties of aerosols at Grand Canyon national park, Atmos. Environ., 34, 3373-3391, 2000.

Malm, W. C. and Day, D. E.: Estimates of aerosol species scattering characteristics as a function of relative humidity, Atmos. Environ., 35, 2845-2860, 2001.

Malm, W. C., Day, D. E., Kreidenweis, S. M., Collett, J. L., and Lee, T.: Humidity-dependent optical properties of fine particles during the Big Bend Regional Aerosol and Visibility Observational Study, J. Geophys. Res., 108, 4279, doi:10.1029/2002JD002998, 2003.

Malm, W. C., Day, D. E., Kreidenweis, S. M., Collett, J. L., Carrico, C., McMeeking, G., and Lee, T.: Hygroscopic properties of an organic-laden aerosol, Atmos. Environ., 39, 4969-4982, 2005.

Meng, Z. Y., Jia, X. F., Zhang, R. J., Yu, X. M., and Ma, Q. L.: Characteristics of PM2.5 at Lin' an Regional Background Station in the Yangtze River Delta Region, J. Appl. Meteorol. Sci., 23, 424-432, 2012.

Morgan, W. T., Allan, J. D., Bower, K. N., Esselborn, M., Harris, B., Henzing, J. S., Highwood, E. J., Kiendler-Scharr, A., McMeeking, G. R., Mensah, A. A., Northway, M. J., Osborne, S., Williams, P. I., Krejci, R., and Coe, H.: Enhancement of the aerosol direct radiative effect by semi-volatile aerosol components: airborne measurements in North-Western Europe, Atmos. Chem. Phys., 10, 8151-8171, doi:10.5194/acp-10-81512010, 2010.

Müller, T., Laborde, M., Kassell, G., and Wiedensohler, A.: Design and performance of a three-wavelength LED-based total scatter and backscatter integrating nephelometer, Atmos. Meas. Tech., 4, 1291-1303, doi:10.5194/amt-4-1291-2011, 2011.

Pan, X. L., Yan, P., Tang, J., Ma, J. Z., Wang, Z. F., Gbaguidi, A., and Sun, Y. L.: Observational study of influence of aerosol hygroscopic growth on scattering coefficient over rural area near Beijing mega-city, Atmos. Chem. Phys., 9, 7519-7530, doi:10.5194/acp-9-7519-2009, 2009.

Pilinis, C., Seinfeld, J. H., and Grosjean, D.: Water content of atmospheric aerosols, Atmos. Environ., 23, 1601-1606, 1989.

Pilinis, C., Pandis, S. N., and Seinfeld, J. H.: Sensitivity of direct climate forcing by atmospheric aerosols to aerosol size and composition, J. Geophys. Res., 100, 18739-18754, 1995.

Qi, H., Lin, W., Xu, X., Yu, X., and Ma, Q.: Significant downward trend of SO2 observed from 2005 to 2010 at a background station in the Yangtze Delta region, China, Sci. China Ser. B, 55, 14511458, 2012.

Quinn, P., Marshall, S., Bates, T., Covert, D., and Kapustin, V.: Comparison of measured and calculated aerosol properties relevant to the direct radiative forcing of tropospheric sulfate aerosol on climate, J. Geophys. Res., 100, 8977-8991, 1995.

Quinn, P. K., Bates, T. S., Baynard, T., Clarke, A. D., Onasch, T. B., Wang, W., Rood, M. J., Andrews, E., Allan, J., Carrico, C.
M., Coffman, D., and Worsnop, D.: Impact of particulate organic matter on the relative humidity dependence of light scattering: A simplified parameterization, Geophys. Res. Lett., 32, L22809, doi:10.1029/2005g1024322, 2005.

Randles, C., Russell, L., and Ramaswamy, V.: Hygroscopic and optical properties of organic sea salt aerosol and consequences for climate forcing, Geophys. Res. Lett, 31, L16108, doi:10.1029/2004GL020628, 2004.

Shen, X. J., Sun, J. Y., Zhang, Y. M., Wehner, B., Nowak, A., Tuch, T., Zhang, X. C., Wang, T. T., Zhou, H. G., Zhang, X. L., Dong, F., Birmili, W., and Wiedensohler, A.: First long-term study of particle number size distributions and new particle formation events of regional aerosol in the North China Plain, Atmos. Chem. Phys., 11, 1565-1580, doi:10.5194/acp-11-15652011, 2011.

Shi, Y., Chen, J., Hu, D., Wang, L., Yang, X., and Wang, X.: Airborne submicron particulate $(\mathrm{PM}<\mathrm{sub}>1</ \mathrm{sub}>)$ pollution in Shanghai, China: Chemical variability, formation/dissociation of associated semi-volatile components and the impacts on visibility, Sci. Total Environ., 473, 199-206, 2014.

Shi, Z., Zhang, D., Hayashi, M., Ogata, H., Ji, H., and Fujiie, W.: Influences of sulfate and nitrate on the hygroscopic behaviour of coarse dust particles, Atmos. Environ., 42, 822-827, 2008.

Sjogren, S., Gysel, M., Weingartner, E., Baltensperger, U., Cubison, M., Coe, H., Zardini, A., Marcolli, C., Krieger, U., and Peter, T.: Hygroscopic growth and water uptake kinetics of two-phase aerosol particles consisting of ammonium sulfate, adipic and humic acid mixtures, J. Aerosol Sci., 38, 157-171, 2007.

Sullivan, R., Moore, M., Petters, M., Kreidenweis, S., Roberts, G., and Prather, K.: Effect of chemical mixing state on the hygroscopicity and cloud nucleation properties of calcium mineral dust particles, Atmos. Chem. Phys., 9, 3303-3316, 2009, http://www.atmos-chem-phys.net/9/3303/2009/.

Sun, J., Zhang, Q., Canagaratna, M. R., Zhang, Y., Ng, N. L., Sun, Y., Jayne, J. T., Zhang, X., Zhang, X., and Worsnop, D. R.: Highly time-and size-resolved characterization of submicron aerosol particles in Beijing using an Aerodyne Aerosol Mass Spectrometer, Atmos. Environ., 44, 131-140, 2010.

Sun, Y., Wang, Z., Dong, H., Yang, T., Li, J., Pan, X., Chen, P., and Jayne, J. T.: Characterization of summer organic and inorganic aerosols in Beijing, China with an Aerosol Chemical Speciation Monitor, Atmos. Environ., 51, 250-259, 2012.

Tang, I. N.: Chemical and size effects of hygroscopic aerosols on light scattering coefficients, J. Geophys. Res.-Atmos, 101, 19245-19250, 1996.

Tobo, Y., Zhang, D., Matsuki, A., and Iwasaka, Y.: Asian dust particles converted into aqueous droplets under remote marine atmospheric conditions, P. Natl. Acad. Sci. USA, 107, 17905-17910, 2010.

Tuch, T. M., Haudek, A., Müller, T., Nowak, A., Wex, H., and Wiedensohler, A.: Design and performance of an automatic regenerating adsorption aerosol dryer for continuous operation at monitoring sites, Atmos. Meas. Tech., 2, 417-422, doi:10.5194/amt-2-417-2009, 2009.

Wang, J. and Martin, S. T.: Satellite characterization of urban aerosols: Importance of including hygroscopicity and mixing state in the retrieval algorithms, J. Geophys. Res.-Atmos., 112, D17203, doi:10.1029/2006JD008078, 2007. 
Wang, L. P., Zhang, B. H., and Zhang, X. W.: Main weather processes in March and April, 2013, Weather Forecast Rev., 5, 1-7, 2013.

Wang, M. X., Ding, X., Fu, X., He, Q., Wang, S., Bernard, F., Zhao, $\mathrm{X}$., and Wu, D.: Aerosol scattering coe_cients and major chemical compositions of fine particles observed at a rural site in the central Pearl River Delta, South China, J. Environ. Sci., 24, 7277, 2012.

Wang, Y., Zhang, X., and Draxler, R. R.: TrajStat: GIS-based software that uses various trajectory statistical analysis methods to identify potential sources from long-term air pollution measurement data, Environ. Modell. Softw., 24, 938-939, 2009.

Weingartner, E., Baltensperger, U., and Burtscher, H.: Growth and structural change of combustion aerosols at high relative humidity, Environ. Sci. Technol., 29, 2982-2986, 1995.

Wiscombe, W. and Grams, G.: The backscattered fraction in twostream approximations, J. Atmos. Sci., 33, 2440-2451, 1976.

Xu, J., Bergin, M., Yu, X., Liu, G., Zhao, J., Carrico, C., and Baumann, K.: Measurement of aerosol chemical, physical and radiative properties in the Yangtze delta region of China, Atmos. Environ., 36, 161-173, 2002.

Xu, X., Lin, W., Wang, T., Yan, P., Tang, J., Meng, Z., and Wang, Y.: Long-term trend of surface ozone at a regional background station in eastern China 1991-2006: enhanced variability, Atmos. Chem. Phys., 8, 2595-2607, doi:10.5194/acp-8-2595-2008, 2008.

Yan, P., Zhang, Y. M., Yang, D. Z., Tang, J., Yu, X. L., Cheng, H. B., and Yu, X. M.: The charactertistic of aerosol ionic size distributions at Lin'an in summer of 2003, Acta Meteor. Sin., 63, 980-987, 2005.

Yan, P., Pan, X., Tang, J., Zhou, X., Zhang, R., and Zeng, L.: Hygroscopic growth of aerosol scattering coefficient: A comparative analysis between urban and suburban sites at winter in Beijing, Particuology, 7, 52-60, 2009.

Zhang, B. and Sun, J.: Analysis of the March 2013 atmospheric circulation and Weather, Meteor. Mon., 39, 794-800, 2013.

Zhang, Y. Y., Zuo, L. F., Ren, X. C., and Cui, J.: Research of the aerosol scattering properties based on evaporation duct, Ship Electron. Eng., 32, 12-14, 2012.
Zhejiang Environmental Protection Bureau (ZEPB): 1999, Annual Report on the State of the Environment of Zhejiang Province, Zhejiang Environmental Protection Bureau, Hangzhou, 1999.

Zhejiang Environmental Protection Bureau (ZEPB): 2006, Annual Report on the State of the Environment of Zhejiang Province, Zhejiang Environmental Protection Bureau, Hangzhou, 21 pp., 2006.

Zhejiang Environmental Protection Bureau (ZEPB): 2012, Annual Report on the State of the Environment of Zhejiang Province, Zhejiang Environmental Protection Bureau, Hangzhou, 29 pp., 2012.

Zhejiang Environmental Protection Bureau (ZEPB): 2013, Annual Report on the State of the Environment of Zhejiang Province, Zhejiang Environmental Protection Bureau, Hangzhou, 33 pp., 2013.

Zieger, P., Fierz-Schmidhauser, R., Gysel, M., Ström, J., Henne, S., Yttri, K. E., Baltensperger, U., and Weingartner, E.: Effects of relative humidity on aerosol light scattering in the Arctic, Atmos. Chem. Phys., 10, 3875-3890, doi:10.5194/acp-10-38752010, 2010.

Zieger, P., Weingartner, E., Henzing, J., Moerman, M., de Leeuw, G., Mikkilä, J., Ehn, M., Petäjä, T., Clémer, K., van Roozendael, M., Yilmaz, S., Frieß, U., Irie, H., Wagner, T., Shaiganfar, R., Beirle, S., Apituley, A., Wilson, K., and Baltensperger, U.: Comparison of ambient aerosol extinction coefficients obtained from in-situ, MAX-DOAS and LIDAR measurements at Cabauw, Atmos. Chem. Phys., 11, 2603-2624, doi:10.5194/acp11-2603-2011, 2011.

Zieger, P., Kienast-Sjögren, E., Starace, M., von Bismarck, J., Bukowiecki, N., Baltensperger, U., Wienhold, F. G., Peter, T., Ruhtz, T., Collaud Coen, M., Vuilleumier, L., Maier, O., Emili, E., Popp, C., and Weingartner, E.: Spatial variation of aerosol optical properties around the high-alpine site Jungfraujoch (3580 m a.s.1.), Atmos. Chem. Phys., 12, 7231-7249, doi:10.5194/acp12-7231-2012, 2012.

Zieger, P., Fierz-Schmidhauser, R., Weingartner, E., and Baltensperger, U.: Effects of relative humidity on aerosol light scattering: results from different European sites, Atmos. Chem. Phys., 13, 10609-10631, doi:10.5194/acp-13-10609-2013, 2013.

Zieger, P., Fierz-Schmidhauser, R., Poulain, L., Müller, T., Birmili, W., Spindler, G., Wiedensohler, A., Baltensperger, U., and Weingartner, E.: Influence of water uptake on the aerosol particle light scattering coefficients of the Central European aerosol, Tellus B, 66, 22716, doi:10.3402/tellusb.v66.22716, 2014. 